
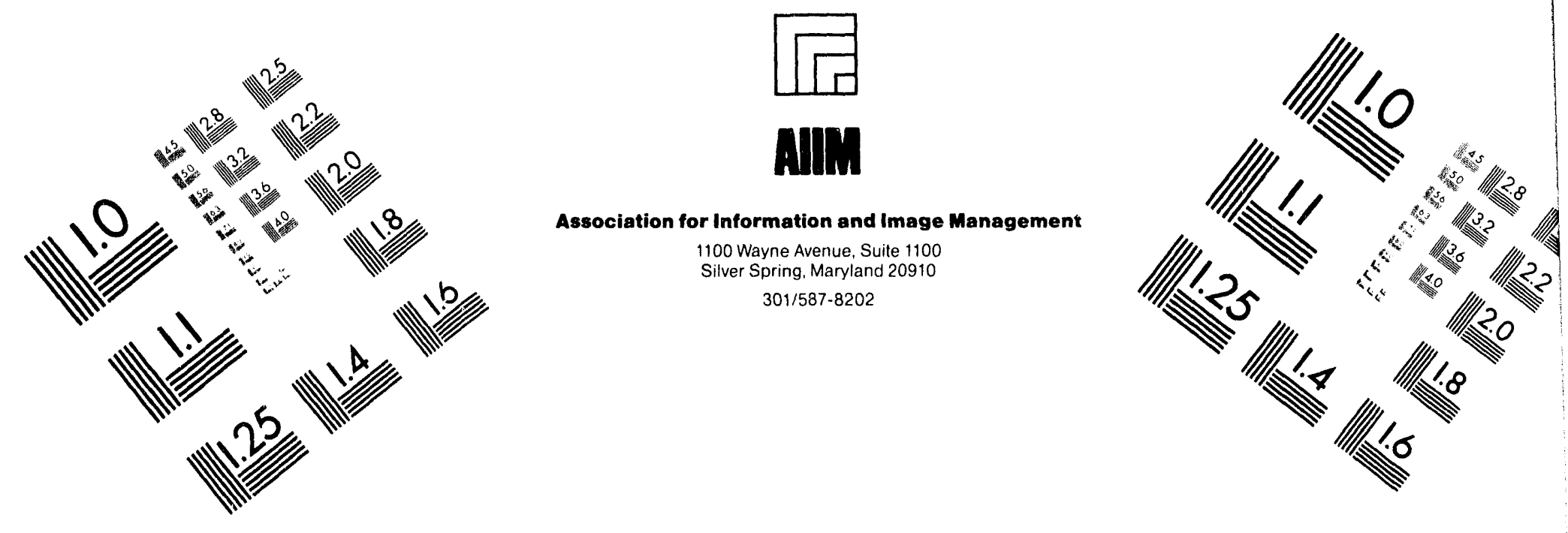

\title{
Centimeter
}

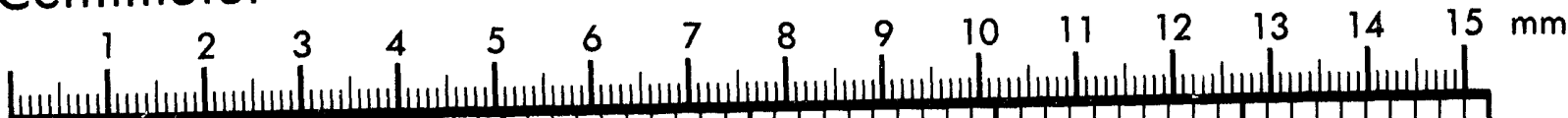

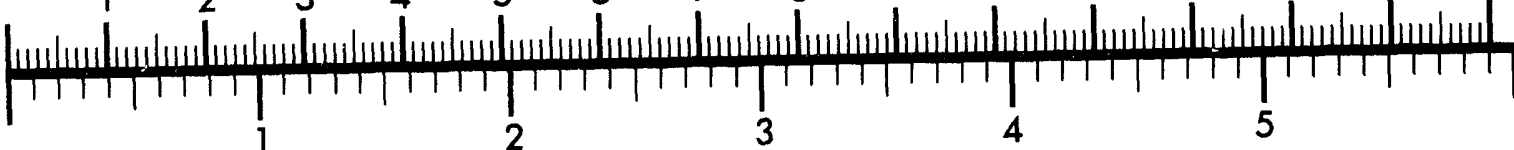
Inches
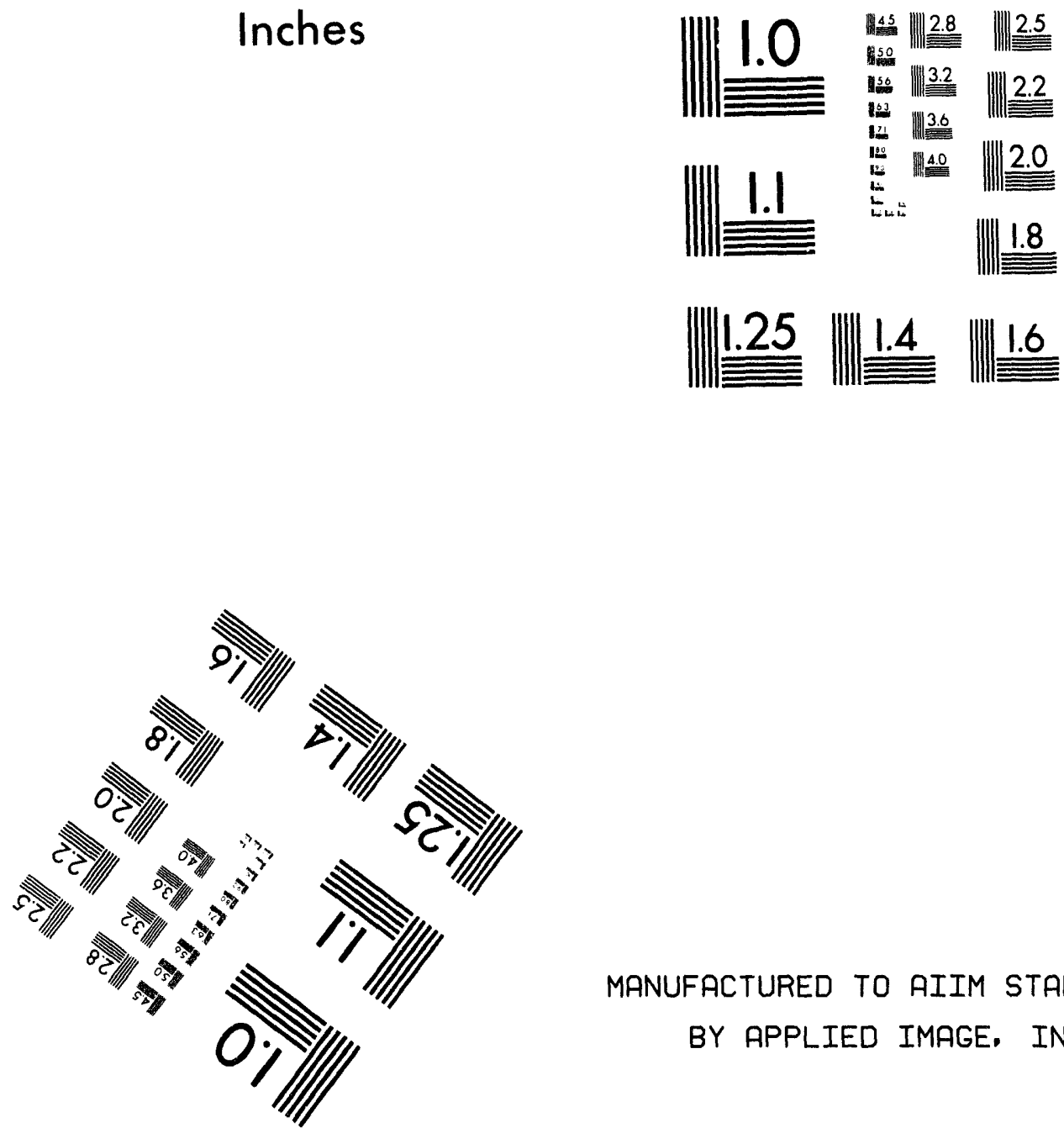

MANUFACTURED TO AIIM STANDARDS BY APPLIED IMAGE, INC.

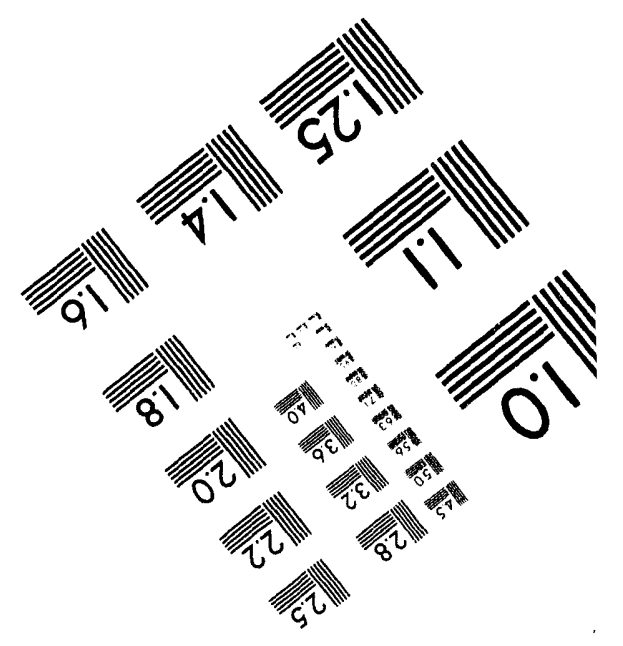



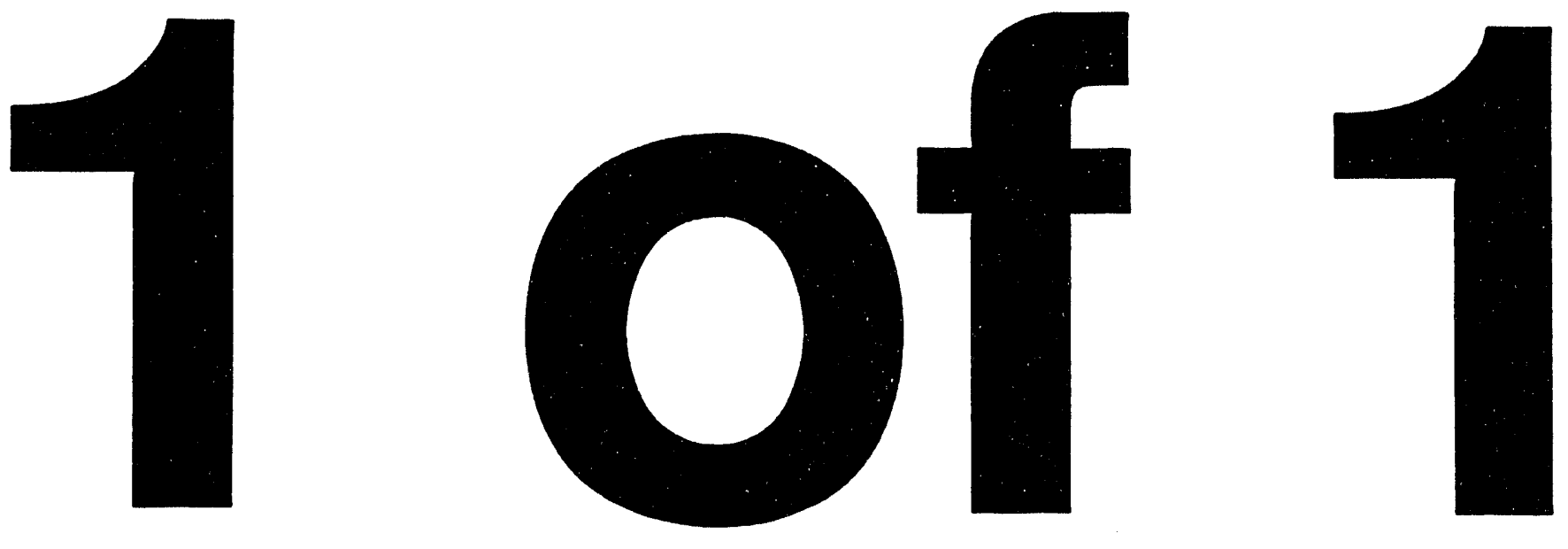


\title{
Evaluation of the Contamination Control Unit During Simulated Transuranic Waste Retrieval
}

\author{
D. N. Thompson \\ A. L. Freeman \\ V. E. Wixom \\ Published November 1993 \\ Idaho National Engineering Laboratory \\ EG\&G Idaho, Inc. \\ Idaho Falls, Idaho 83415
}




\section{Evaluation of the Contamination Control Unit During Simulated Transuranic Waste Retrieval}

EGG-WTD-10973

Prepared by

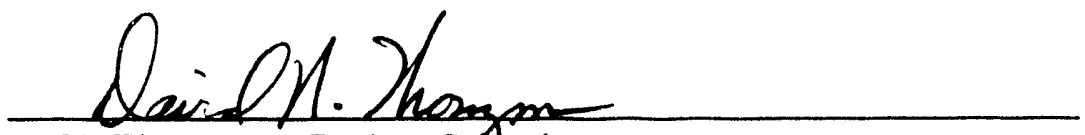

D. N. Thompson, Project Sclentist

Radiation Measurements and Development Unit

Reviewed by

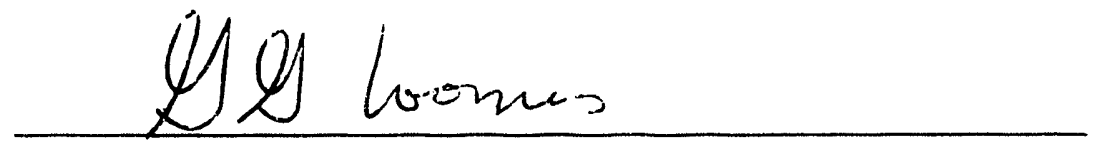

G. G. Loomis, Project Manager

Buried Waste Integrated Demonstration

Approved by

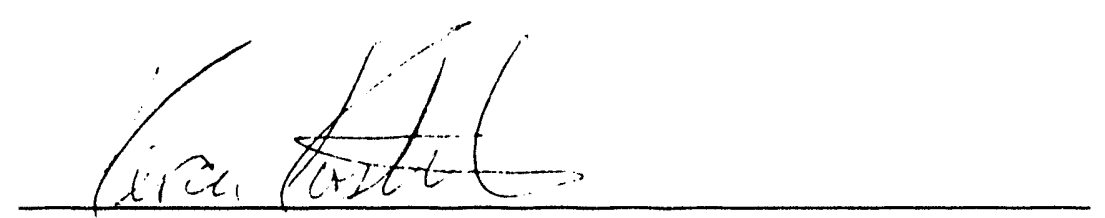

K. M. Kostelnik, Coordinator

Buried Waste Integrated Demonstration
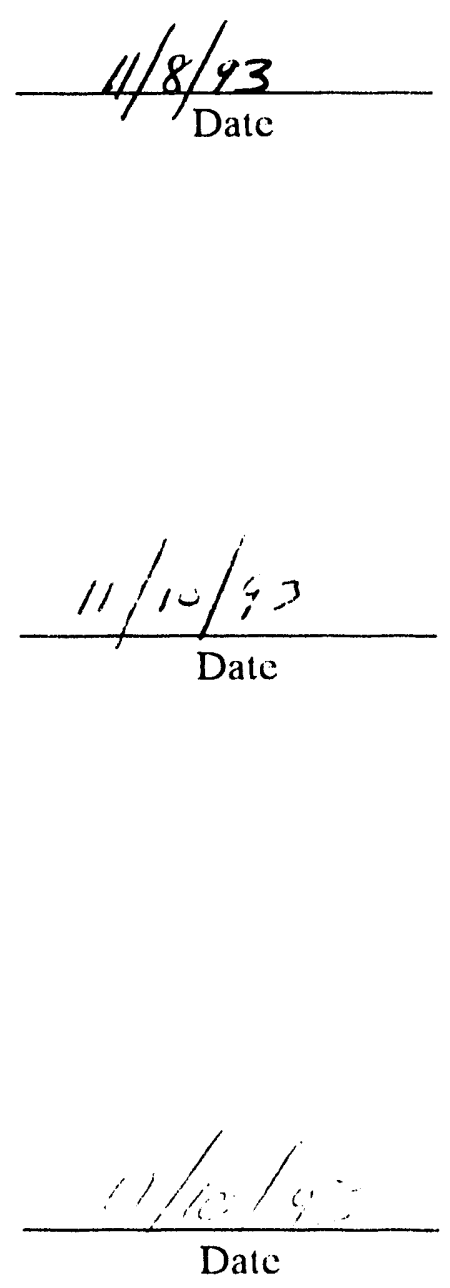


\begin{abstract}
This report presents the results of a field demonstration at the INEL of the Contamination Control Unit (CCU). The CCU is a ficld deployable self-contained trailer mounted system to control contamination spread at the site of transuranic (TRU) handling operations. This is accomplished primarily by controlling dust spread. This demonstration was sponsored by the U.S. Department of Energy's Office of Waste Technology Development Buried Waste Integrated Demonstration.

The CCU, housed in a mobile trailer for easy transport, supports four different contamination control systems: water misting, dust suppression application, soil fixative application, and vacuuming operations. Assessment of the CCU involved laboratory operational performance testing, operational testing and contamination control at a decommissioned Idaho National Engineering Laboratory reactor, and field testing in conjunction with a simulated TRU buricd waste retricval effort at the Cold Test Pit.
\end{abstract}




\section{SUMMARY}

This report presents field demonstration results of the Contamination Control Unit (CCU). The CCU was developed by the Buried Waste Integration Demonstration (BWID) for the U.S. Department of Energy (DOE) Office of Technology Development. The CCU is a self-contained, field deployable trailer-mounted system designed to control contamination spread at the site of TRU handling operations. The systems contained in the unit are capable of performing multiple contamination control functions in dusty conditions where contamination spread is linked with dust spread. Examples of the system's capabilities are buried TRU and low-level waste retricval and treatment and emergency response for hazardous and radioactive materials.

The CCU is capable of dispensing soil fixatives, dust suppression agents, misted water, and uses a vacuum system. The Dryfog Ultrasonic Misting System uses a specially designed nozzle to mix air and water to create a fine cone of mist. The misting heads are placed in strategic positions without interfering with other local activities to provide contamination control for digging and dumping operations. In the demonstration, the Dryfog Ultrasonic Misting System was used to control aerosolized soil and provided adequate dust control. Misting in wind controlled conditions proved to be effective. The soil fixative application system uses a soil fixative ( $3 \mathrm{M}$ Foam) mixed with water to create a pale yellow foam material that is dispensed using volume expansion nozzles. This product provides a long-term, vapor suppressing foam for covering uneven contaminated soil (e.g., steep sloping digfaces).

The systems in the CCU are ready for full-scale testing or application. All systems have been tested thoroughly and evaluated qualitatively. The CCU has already been deployed for contaminated soil excavation operations from the Westinghouse Hanford 116-F-4 waste site (a $100 \mathrm{~F}$ Area pluto crib) to control TRU and low-level soil contamination and to support the testing of different types of dust control products.

The CCU performed as expected but especially well during a simulated TRU buried waste retrieval demonstration. The CCU did not have any down time, and all systems worked properly. Personnel operating the CCU became experienced and proficient by the end of the demonstrations.

The CCU is also ready to provide for emergency response. There are products immediately available to provide contamination control using soil fixation (3M Foam) and dust suppression (Flambinder), if needed. The CCU can be moved throughout the DOE complex for immediate use (e.g., Fernald, Savannah River Site, and Hanford Site).

All of the dust control products were individually tested in glove box and engineering scale experiments. The field tests were qualitative to show the fieldability of the apparatus and deployability of the dust control products. Obscrvations of the apparatus and dust control products are provided below.

The $3 \mathrm{M}$ Foam is an adequate fixative that shows field deployable attributes, but it has cost constraints. The key to optimum performance of $3 \mathrm{M}$ Foam is using the product in the proper situation and under the right conditions. Applying the $3 \mathrm{M}$ Foam product as a soil fixative between digging operations of a simulated TRU buried waste retricval effort (in Cell 4 of the Remote Excavation System demonstration) proved to be inappropriate for a real world application. The best 
application for this product is covering dry, contaminated soil or covering items with loose contamination that are expected to be left undisturbed inside of a containment structure (e.g., Pit 9 reclamation).

The dust suppression application system is the simplest, yet the most versatile system contained on the CCU because any type of dust suppressant, surfactant, or fixative (also known as a crusting agent) that solubilizes readily with water can be used with this system.

Of all of the products tested by the CCU, Flambinder (calcium lignosulfonate) was the best overall. XDCA (a sugar beet polysaccharide) is also adequate, and both are more durable than WenDon (an encapsulant). Flambinder was best suited for contamination control in traffic areas, in the excavation area, and on the dumping area. The XDCA was best suited for contamination control on smooth, light traffic areas. The potato starch product was best for short-term, steep digface fixation of dust and loose contamination.

The potato starch mixture formed a protective crust that was not readily resolubilized. The crust maintained its integrity for at least 1 week before ultraviolet rays began to degrade its quality. The starch adhered to vertical soil slopes extremely well when applied slowly.

The vacuum system in the CCU is a nuclear grade, high efficiency particulate air (HEPA) filtered system. The vacuum system is capable of removing loose particulate debris including small particles in the micron range up to large debris $1.5 \mathrm{in}$. in diameter. The vacuum system provides a means to rapidly decontaminate equipment, personnel, and work areas.

Although the vacuum system performed as expected, it needs further ev aluation using sieved soil spiked with rare earth tracer. A test like this would demonstrate the contamination control of the vacuum system and identify possible contamination problems that could occur within the system or trailer.

Overall, in the field, the CCU achieved dust control efficiencies equivalent to those obtained during laboratory testing. A dust control elficiency of $70 \%$ was obtained by dust loadings on filters for excavation cases with and without contamination control. 


\section{ACKNOWLEDGMENTS}

The authors would like to thank Alice Caponiti, U.S. Department of Energy, Headquarters, for her contribution to the Contamination Control Unit performance testing. She assisted with air sampling, rare earth tracer spiking of the Cold Test Pit, and spraying the $3 \mathrm{M}$ Foam product. She also became proficient at operating all of the systems on the CCU.

The authors would also like to thank Tamera Fields, Cynthia Stewart, and Zack Fuchs for their assistance when the CCU crew was shorthanded. Without their help, the CCU demonstrations would not have been as successful. 


\section{CONTENTS}

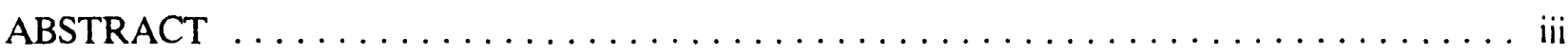

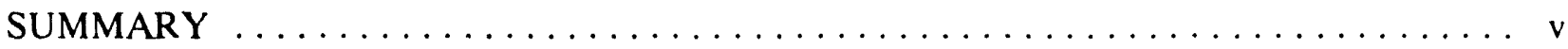

ACKNOWLEDGMENTS $\ldots \ldots \ldots \ldots \ldots \ldots \ldots \ldots \ldots \ldots \ldots \ldots$ vii

ACRONYMS $\ldots \ldots \ldots \ldots \ldots \ldots \ldots \ldots \ldots \ldots \ldots \ldots \ldots \ldots \ldots \ldots \ldots \ldots \ldots \ldots \ldots \ldots \ldots$

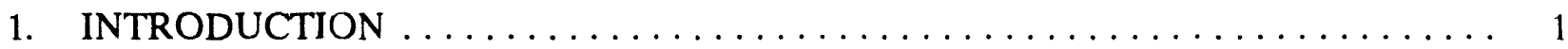

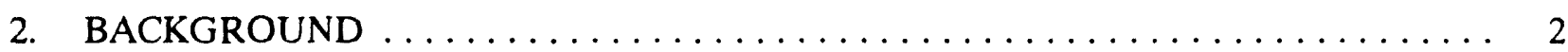

3. PROJECT OBJECTIVES $\ldots \ldots \ldots \ldots \ldots \ldots \ldots \ldots \ldots \ldots \ldots \ldots \ldots \ldots \ldots$

4. CCU CONTAMINATION CONTROL SYSTEMS $\ldots \ldots \ldots \ldots \ldots \ldots \ldots \ldots \ldots$

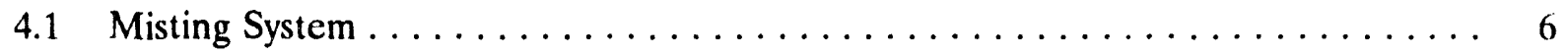

4.1.1 Description of the Misting System $\ldots \ldots \ldots \ldots \ldots \ldots \ldots \ldots$

4.2 Soil Fixative (3M Foam) Application System $\ldots \ldots \ldots \ldots \ldots \ldots \ldots \ldots \ldots$

4.2.1 Description of the Soil Fixative Application System $\ldots \ldots \ldots \ldots \ldots \ldots$

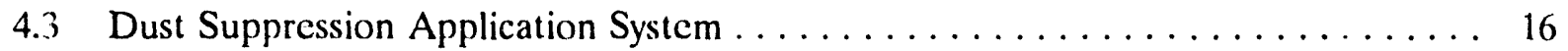

4.3.1 Description of the Dust Suppression Application System $\ldots \ldots \ldots \ldots \ldots$

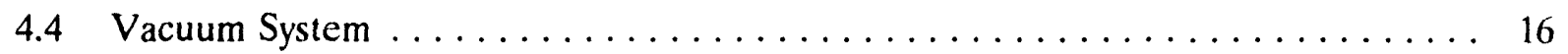

4.4.1 Description of the Vacuum System ................ 16

5. DESCRIPTIONS OF DEMONSTRATIONS $\ldots \ldots \ldots \ldots \ldots \ldots \ldots \ldots \ldots \ldots$

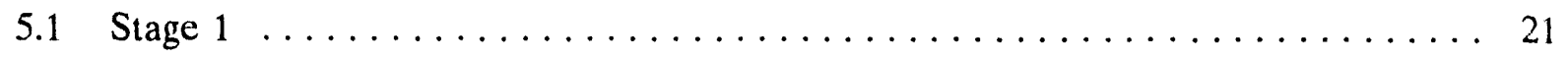

5.1.1 Stage 1 Testing Setup of the Misting System . . . . . . . . . . . 21

5.1.2 Stage 1 Testing Setup of the Fixative System $\ldots \ldots \ldots \ldots \ldots \ldots \ldots$

5.1.3 Stage 1 Testing and Setup of the Dust Suppression System . . . . . . . . . 23

5.1 .4 Stage 1 Testing and Sctup of the Vacuum System . . . . . . . . . . . 23

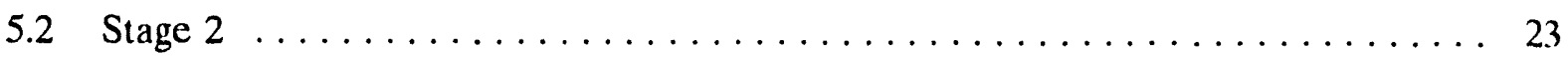

5.2.1 Stage 2 Testing and Sctup of the Fixative System . . . . . . . . . . . 24

5.2 .2 Stage 2 Testing and Setup of the Dust Suppression System . . . . . . . . . 24 


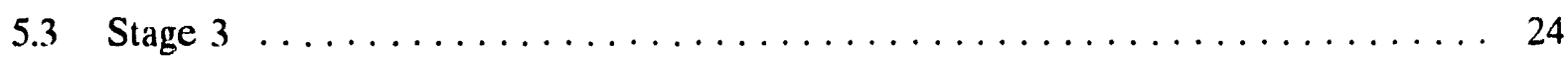

5.3.1 Stage 3 Testing and Setup of the Misting System $\ldots \ldots \ldots \ldots \ldots \ldots$

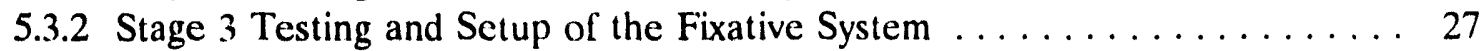

5.3.3 Stage 3 Testing and Setup of the Potato Starch System . . . . . . . . . . 28

5.3.4 Stage 3 Testing and Setup of the Dust Suppression System . . . . . . . . 28

5.3 .5 Stage 3 Air Sampling Systems . . . . . . . . . . . . . . . . . . . . 29

6. DEMONSTRATION RESULTS $\ldots \ldots \ldots \ldots \ldots \ldots \ldots \ldots \ldots \ldots \ldots \ldots \ldots \ldots \ldots$

6.1 Stage 1 Results of the Misting System $\ldots \ldots \ldots \ldots \ldots \ldots \ldots \ldots \ldots \ldots$

6.2 Stage 1 Results of the Fixative System $\ldots \ldots \ldots \ldots \ldots \ldots \ldots \ldots \ldots \ldots \ldots$

6.3 Stage 1 Results of the Dust Suppression System $\ldots \ldots \ldots \ldots \ldots \ldots \ldots \ldots$

6.4 Stage 1 Results of the Vacuum System $\ldots \ldots \ldots \ldots \ldots \ldots \ldots \ldots \ldots \ldots \ldots \ldots$

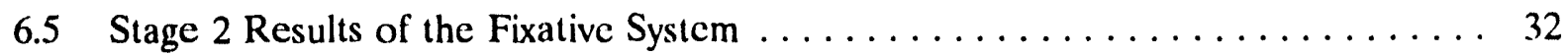

6.6 Stage 2 Results of the Dust Suppression System $\ldots \ldots \ldots \ldots \ldots \ldots \ldots \ldots$

6.7 Stage 3 Results of the Misting System $\ldots \ldots \ldots \ldots \ldots \ldots \ldots \ldots \ldots \ldots \ldots \ldots \ldots$

6.8 Stage 3 Results of the Fixative System $\ldots \ldots \ldots \ldots \ldots \ldots \ldots \ldots \ldots \ldots \ldots \ldots \ldots \ldots$

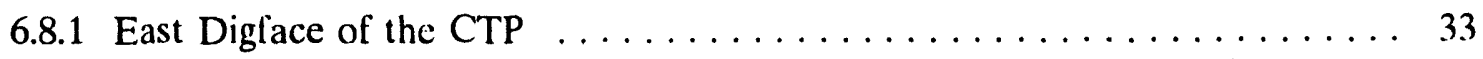

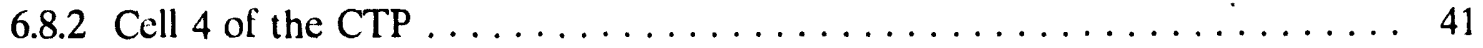

6.9 Stage 3 Results of the Potato Starch System $\ldots \ldots \ldots \ldots \ldots \ldots \ldots \ldots$

6.10 Stage 3 Results of the Dust Suppression System $\ldots \ldots \ldots \ldots \ldots \ldots \ldots \ldots$

6.11 Stage 3 Quantitative Dust Mcasurement Results ............... 44

7. COST ANALYSIS $\ldots \ldots \ldots \ldots \ldots \ldots \ldots \ldots \ldots \ldots \ldots \ldots \ldots$

8. LESSONS LEARNED $\ldots \ldots \ldots \ldots \ldots \ldots \ldots \ldots \ldots \ldots \ldots \ldots \ldots \ldots \ldots$

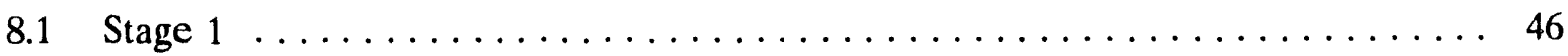

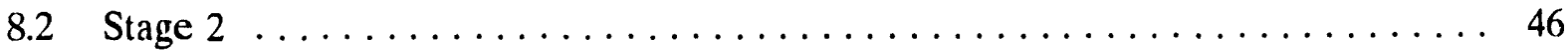

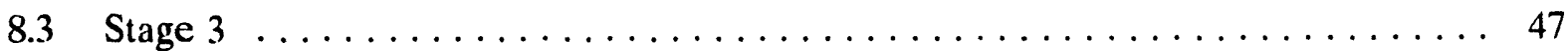

9. CONCLUSIONS $\ldots \ldots \ldots \ldots \ldots \ldots \ldots \ldots \ldots \ldots \ldots \ldots \ldots \ldots \ldots$ 
10. RECOMMENDATIONS $\ldots \ldots \ldots \ldots \ldots \ldots \ldots \ldots \ldots \ldots \ldots \ldots \ldots \ldots \ldots$

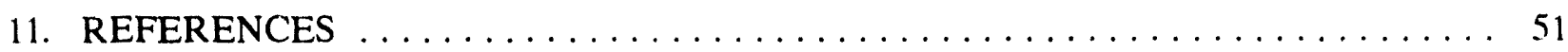

Appendix A--Quantitative Air Sampling Data $\ldots \ldots \ldots \ldots \ldots \ldots \ldots \ldots \ldots \ldots \ldots \ldots$

\section{FIGURES}

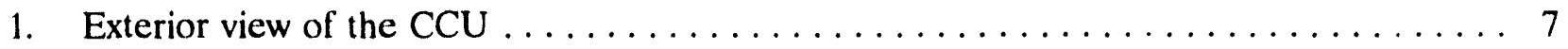

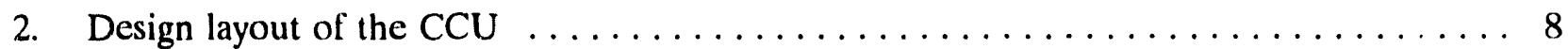

3. Rear of CCU showing the hose reels, low water alarm, gauges, reel clutches, and

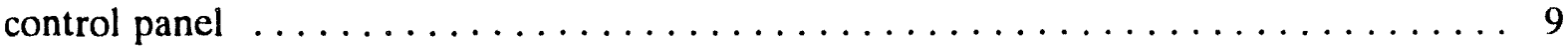

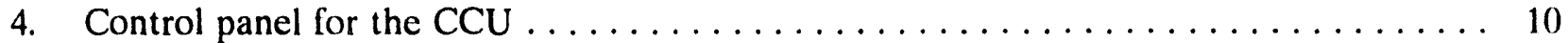

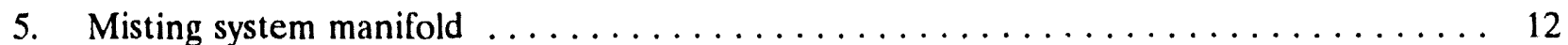

6. Quick disconnect hose attachments from the manifold to the misting nozzles $\ldots \ldots \ldots 13$

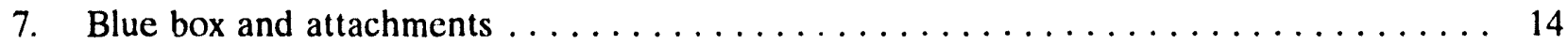

8. Blue box product hose position for flushing $\ldots \ldots \ldots \ldots \ldots \ldots \ldots \ldots \ldots$

9. Dust suppression and misting motors and pumps $\ldots \ldots \ldots \ldots \ldots \ldots \ldots \ldots$

10. Dust suppression spray gun $\ldots \ldots \ldots \ldots \ldots \ldots \ldots \ldots \ldots \ldots \ldots \ldots \ldots \ldots$

11. Vacuum system motor and debris container $\ldots \ldots \ldots \ldots \ldots \ldots \ldots \ldots \ldots$

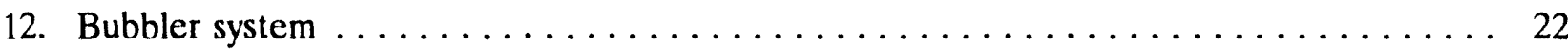

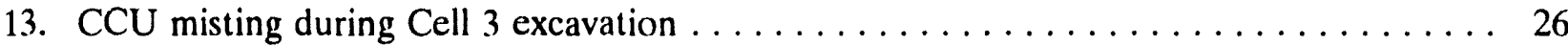

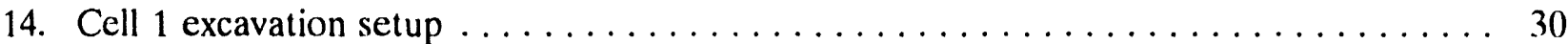

15. Nozzle operator using the $3 \mathrm{M}$ Foam low expansion nozzle $\ldots \ldots \ldots \ldots \ldots \ldots \ldots$

16. View 1 of nozzle operator using the $3 \mathrm{M}$ Foam high expansion nozzle $\ldots \ldots \ldots \ldots \ldots$

17. View 2 of nozzle operator using the $3 \mathrm{M}$ Foam high expansion nozzle $\ldots \ldots \ldots \ldots$

18. $3 \mathrm{M}$ Foam showing coverage capability after curing 24 hours $\ldots \ldots \ldots \ldots \ldots \ldots \ldots$

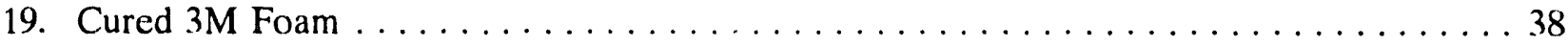




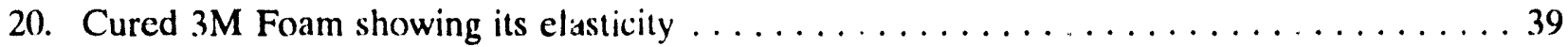

21. Nozzle operator using $3 \mathrm{M}$ Foam without stabilizer $(\mathrm{FX9161)} \ldots \ldots \ldots \ldots \ldots$

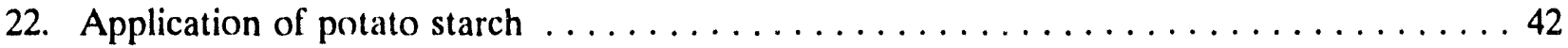




\section{ACRONYMS}

$\begin{array}{ll}\text { BWID } & \text { Buried Waste Integrated Demonstration } \\ \text { CCU } & \text { Contamination Control Unit } \\ \text { DOP } & \text { Cold Test Pit } \\ \text { EBR-1 } & \text { U.S. Department of Energy } \\ \text { FY } & \text { Fiscal year } \\ \text { HEPA } & \text { High efficiency particulate air } \\ \text { INEL } & \text { Idaho National Engineering Laboratory } \\ \text { RES } & \text { Remote Evacuation System } \\ \text { RWMC } & \text { Radioactive Waste Management Complex } \\ \text { SCBA } & \text { Self-contained breathing apparatus } \\ \text { TDI } & \text { Toluene diisocyanate } \\ \text { TRU } & \text { Transuranic }\end{array}$




\section{Evaluation of the Contamination Control Unit During Simulated Transuranic Waste Retrieval}

\section{INTRODUCTION}

This report presents the results of the field performance testing of the Contamination Control Unit (CCU) during a simulated transuranic (TRU) buried waste retrieval operation. The CCU is a mobile trailer capable of dispensing soil fixatives, dust suppression agents, misted water, and uses a vacuum system. These systems perform multiple contamination control functions in support of the Office of Waste Technology Development Buried Waste Integrated Demonstration (BWID) projects and TRU and low-level waste retrieval operations. The CCU is also available to provide emergency response for hazardous and radioactive materials incidents. Field demonstrations of the CCU were performed in the spring and summer of 1993 at the Idaho National Engincering Laboratory (INEL).

The following information is provided in this report: background about the CCU, objectives of the performance tests, descriptions of experiments and demonstrations, methods used to evaluate the systems, and results of the evaluations. The figures and photographs have been provided to show the testing setups, to simplify procedural explanations, and to help clarify the methods used and the subsequent results. 


\section{BACKGROUND}

One of the options for the remediation of the Radioactive Waste Management Complex (RWMC) include the retrieval and treatment of over 2 million cubic feet of TRU contaminated wastes commingled with up to 5 million cubic feet of soil, which were shipped to the INEL from weapons fabrication operations at the Rocky Flats Plant. The wastes are currently buried in shallow land filled pits and trenches. Based on retrieval operations performed during the mid-1970s, most of the containers have lost their integrity, and the TRU and hazardous materials contaminants have leached into the surrounding soil. In addition, retrieval operations are expected to further commingle the waste with the soil. For this reason, BWID has sponsored background glove box and engineering scale experiments into contamination control at the INEL.

During retrieval operations, it is expected that fugitive dusts will be generated, and the TRU contaminated and/or hazardous materials will become airborne. Because of the high toxicity and low body burdens for TRU and/or hazardous materials, it is important to minimize the generation and spread of fugitive dusts during waste retrieval operations. Initial INEL research involving contamination control included investigating current, off-the-shelf dust control systems used in the mining industry. Several different products and application systems were identified, and testing was conducted to evaluate which product and application systems would perform the best on INEL type soils. ${ }^{1,2}$ In 1989 , a system was designed to control the generation and spread of contamination during retrieval operations. ${ }^{3}$ This system used containment structures, robotics equipment, rapid monitoring systems, and dust control techniques to provide maximum safety to the environment and personnel during operations.

During fiscal year (FY)-92 design and procurement was initiated to build a single trailer to house dust suppression and soil fixative application systems. The CCU was originally built to support the BWID projects. Additional uses included dust control during waste retrieval operations, stabilizing or controlling contaminated soil sites, and providing emergency response capability in case of a hazardous or radioactive materials incident.

Many dust suppression and soil lixative products were tested for dust control capability, moisture retention, ease of application, cure times, and maintainability in previous studies ${ }^{1}$ and can be applied using the CCU application systems. The dust control systems used in the CCU included (a) a soil fixative system that uses chemicals to trap contaminants between the soil surface and the air for nontraffic areas, (b) a dust suppression system, which uses chemicals or natural agents to control contamination spread in traffic areas, (c) a misting system to control airborne dusts during digging and dumping operations, and (d) a vacuum system to decontaminate equipment and hot spot areas. During FY-92, the final selection of products and application systems was made and are listed below:

- 3M Foam, using the Williams Model 80 foam generating system, and a potato starch from Penwest Foods were chosen as soil fixatives.

- Flambinder (calcium lignosulfonate) and XDCA, a natural polysaccharide (sugar beet product), were chosen as dust suppression agents.

- Dryfog Ultrasonic Misting System heads (nozzles), manufactured by SONICS, Inc., were chosen for the misting system. 
- Dustcontrol Model DC 5500, a nuclear grade vacuum system, manufactured by Transmatic Corp., was selected for the vacuum system.

Test objectives, detailed experimental procedures, and data quality objectives needed to perform the field demonstrations are summarized in Test Plan for the Field Evaluation and Demonstration of the Contamination Control Unit. ${ }^{4}$ The demonstrations and evaluations were conducted under a technology agreement with BWID that originated from the Technical Task Plans ID-121210 and RL-432002 (polysaccharide evaluation). 


\section{PROJECT OBJECTIVES}

The primary objective of the CCU testing was to determine its capabilitics, applications, and limitations for various project support and emergency response in actual field conditions. The secondary objective was to produce an operations manual.

The CCU systems were performance tested in a laboratory setting using water to determine pressure settings and product consumption rates, to examine time frames for dispensing products, to verify the functioning of alarms and automatic pump shutoffs, to evaluate the application effects of using different product nozzles, and to discover and repair any deficiencies (e.g., leaks and electrical failure) in the system.

At an area near the INEL's decommissioned Experimental Breeder Reactor 1 (EBR-1) and at the Cold Test Pit (CTP), the CCU systems were tested with actual dust suppression and fixative products to determine the need for "line tuning" the pressure settings, dispensing time frames, alarm and pump shutoff time frames, and nozzle selection effects with each product. This application of the CCU increased experience and knowledge of the CCU's capabilities. An operations manual was written for this system based on these preliminary experiments.

The CCU systems were tested for operational facility and effectiveness during a simulated TRU buried waste retrieval demonstration at the Remote Excavation System Demonstration in June and July of 1993. These demonstrations had the following specific objectives:

- Evaluate at full scale the capability of the dust control products to control the spread of dust during the demonstration. This would be assessed by performing retrieval with and without application of the dust control systems. During these tests, air particulate samples would be obtained with high and low-volume air samplers, and the filter weights compared.

- Evaluate the reliability of the CCU to dispense contamination control products without causing clogging problems in the system or nozzle, plugging of the vacuum lines, or any other major failure. This would be evaluated after each application of the products.

- Evaluate the capability to dispense dust control products and vacuum in an actual field application. The capability will be cvaluated by forcing all vacuum and dispensing hoses through an entire range of motion expected during remediation activities. A successful demonstration will be if the apparatus performs in the RWMC environment with no major equipment failure during the demonstration. The CCU will be deemed operationally ready if the results of the air sampling from the field demonstration show that each of the products used in full-scale demonstration perform within a specific range. This range was identified from earlier studies on dust control. ${ }^{1,2}$ These studies showed that each of the products employed by the CCU had a dust control efficiency under laboratory controlled conditions of between 75 to $95 \%$. The CCU will be considered operationally ready if by using these products with the dust suppression agents applied to vehicle traffic areas, misting systems used over digging and/or dumping areas, and soil fixatives applied to the retrieval areas, a minimum dust control efficiency can be obtained in the containment enclosure of $75 \%$ or greater when compared to conditions with no contamination control techniques in use. 
- Evaluate the compatibility of the $\mathrm{CCU}$ operation with other retrieval equipment such as the excavator and video cameras used to control the vehicle. This will be qualitatively evaluated by observing operational difficulties caused by using the dust control products.

In addition to the preceding major objectives, the following qualitative objectives were examined.

- Evaluate the ability of the soil fixatives, 3M Foam and potato starch, to be used effectively and compatibly with other necessary retrieval operations.

- Evaluate the product performance and mean time to failure for each system application of the CCU.

- Make recommendations on design or equipment modifications based on the qualitative methods.

- Perform an initial field evaluation of the ability to apply immobilization materials and the range of application using each of the systems installed in the CCU.

- Evaluate the dust control efficiency of the natural polysaccharides to immobilize surface contamination or suppress airborne contamination.

- Evaluate the extent, if any, that additional waste is generated.

To meet these objectives, data quality was verified using peer review by the technical leader of the Radiation Measurements and Development Unit. ${ }^{4}$ The following accuracy specifications were applied:

- Flow measurements would be within $\pm 10 \%$. Ten percent was chosen because the vendor calibration data suggest that this is achievable.

- Mass measurements would be within $\pm 0.0001 \mathrm{~g}$.

- Total volume of product used on a test area would be estimated within \pm 10 gal. Ten gallons was chosen because it is an easily observable quantity relative to the tank size containing the product.

- Total area covered by the products would be estimated within $\pm 2 \mathrm{yd}^{2}$. Two square yards was chosen because of the nature in controlling the product from the spray nozzles. 


\section{CCU CONTAMINATION CONTROL SYSTEMS}

The CCU consists of a $9 \times 24$-ft long enclosed trailer manufactured by Wells Cargo Company in Salt Lake City, Utah (see Figure 1). The trailer has a dual tandem axle with a standard $25 / 16$-in. ball hitch. A diagram of the trailer showing the placement of the systems is shown in Figure 2. The trailer contains the application systems for fixatives, dust suppressants, misting, and vacuuming. The trailer requires access to a three-phase $480 \mathrm{~V}$ power supply either from a building hookup or portable $50 \mathrm{~kW}$ generator. The portable generator must be capable of handling a 50 to $60 \mathrm{amp}$ load when all systems are operating simultancously (however, they will not be started simultaneously). Operation of the trailer requires a minimum of two or three people, depending on which system is being used.

Contamination control application systems are arranged in the trailer for proper weight distribution and to allow easy entry for maintenance and service via two single doors and three sets of double doors. Attached to the outside of the trailer are lock catches mounted to support and lock doors in an open position and to keep them braced during windy conditions. On the driver's side of the trailer are double doors allowing access to the vacuum motor, fixative system motor and pump, water tanks, air compressor, and power (breaker) boxes. A single door, on this same side, allows access to the bubbler system controls, water tanks, and belts for the misting system and dust suppression motors. On the passenger side of the trailer are double doors allowing access to the vacuum system, air compressor, power (breaker) boxes, fixative motor and pump, and water tanks. A single door on the passenger side allows access to the misting and dust suppression pumps, misting filtration canister, and suction control line for dust suppression products. The large double doors at the rear of the trailer allow access to the hose reels, main control panel, gauges, spray system switch, and the audible alarm and switch shown in Figure 3. Each hose reel has a clutch release lever contiguous to the reel as an added safety feature. Each hose is at least $100 \mathrm{ft}$ long and is designed to accept line pressures up to $250 \mathrm{psi}$. The control panel, shown in Figure 4, allows the operator to activate and control each application system. The hoses can be recled in and out, fluid flow or vacuum suction can be started and stopped, and interior and exterior lights can be operated using these controls.

\subsection{Misting System}

\subsubsection{Description of the Misting System}

The Dryfog Ultrasonic Misting System uses a specially designed nozzle to mix air and water to create a fine cone of mist. The misting heads will be placed in strategic positions, without interfering with other local activities, to provide contamination control for digging and dumping operations. The misting heads require a clean water supply. A filter canister prevents particulate (extraneous material such as vegetation, dirt, or hard water deposits) up to 50 microns from accidentally passing through the hoses to the misting heads. The misting system in the CCU contains a 300-gal water supply, an air compressor, and a pump to provide water pressure at the misting heads. The trailer is designed to operate up to six heads either individually or in any combination. Each misting head can be attached to its own stand and positioned from 1 to $15 \mathrm{ft}$ high over the area to be misted, depending on the control requirements. The air and water lines from the misting hose reel are connected to a spray manifold, a junction where air and water from the trailer each pass through a ball valve and 


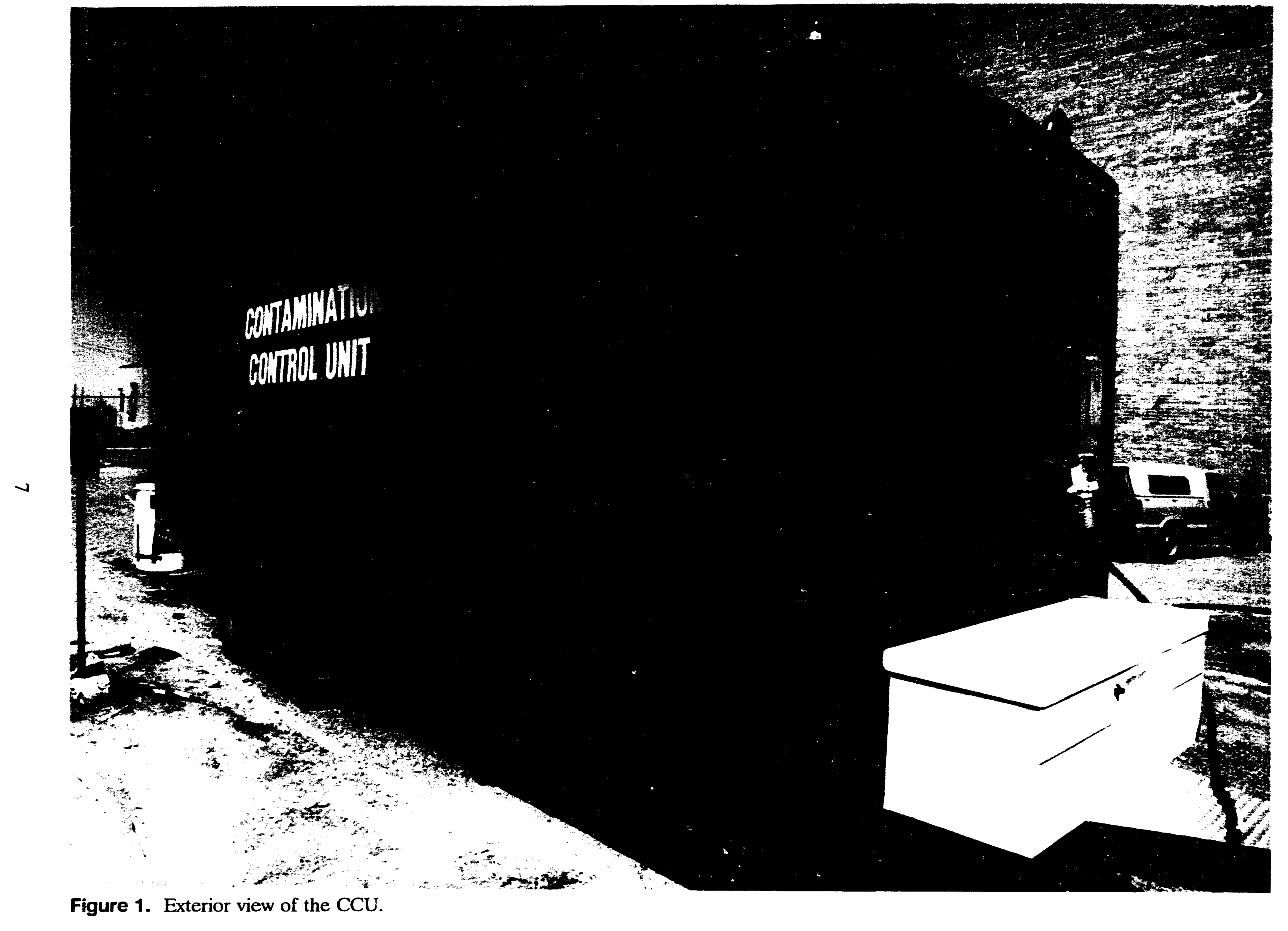




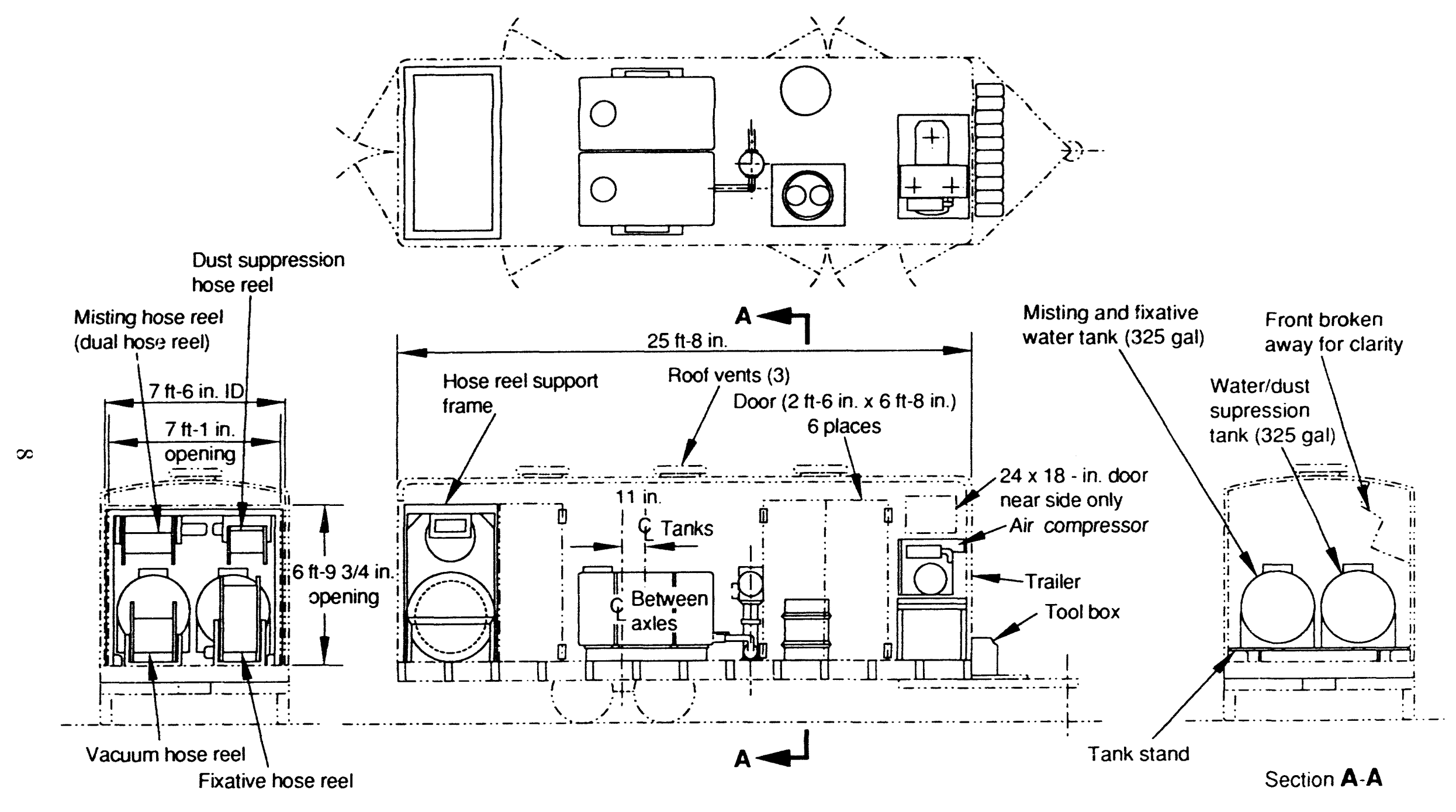

Figure 2. Design layout of the CCU. 


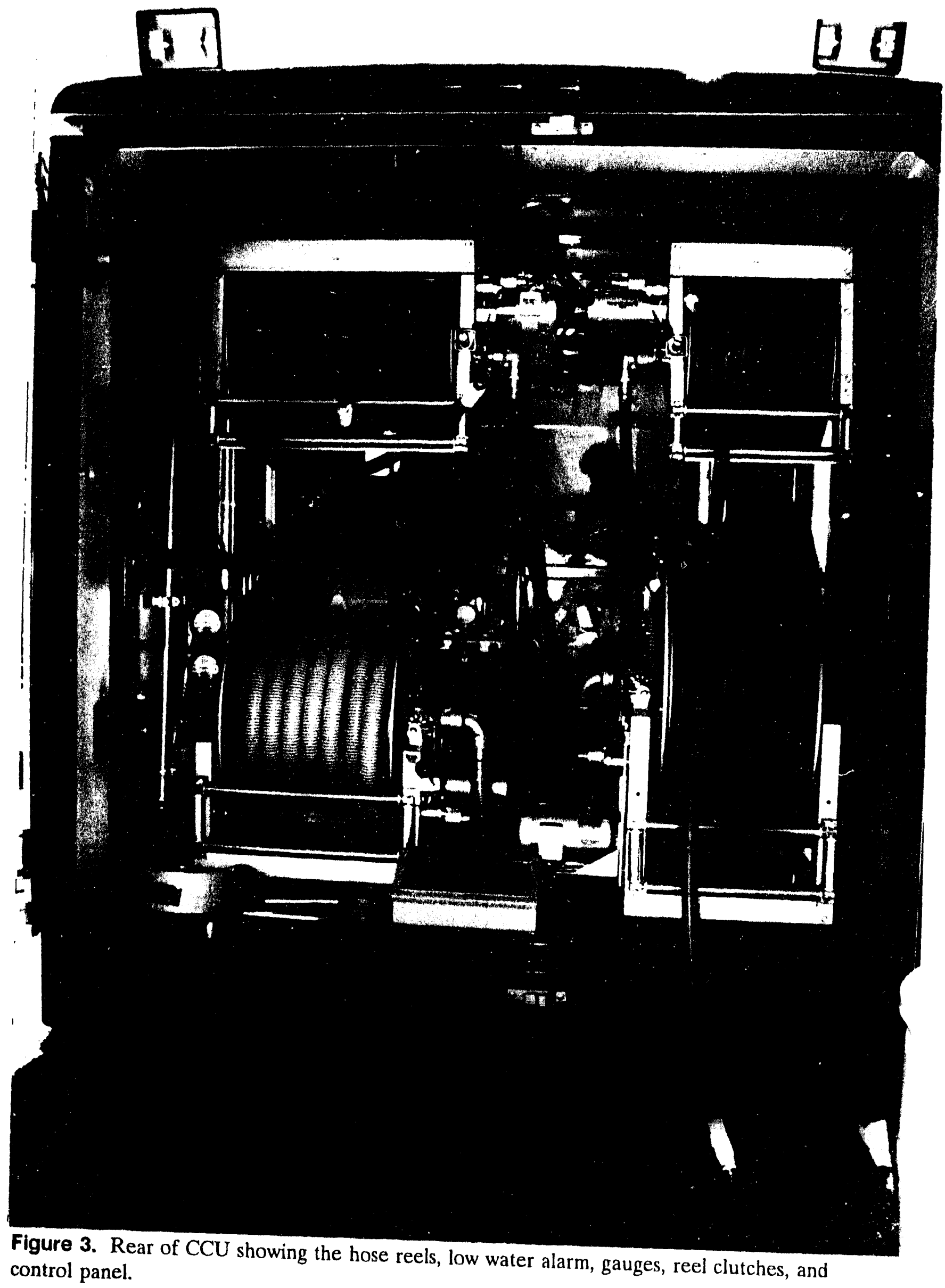




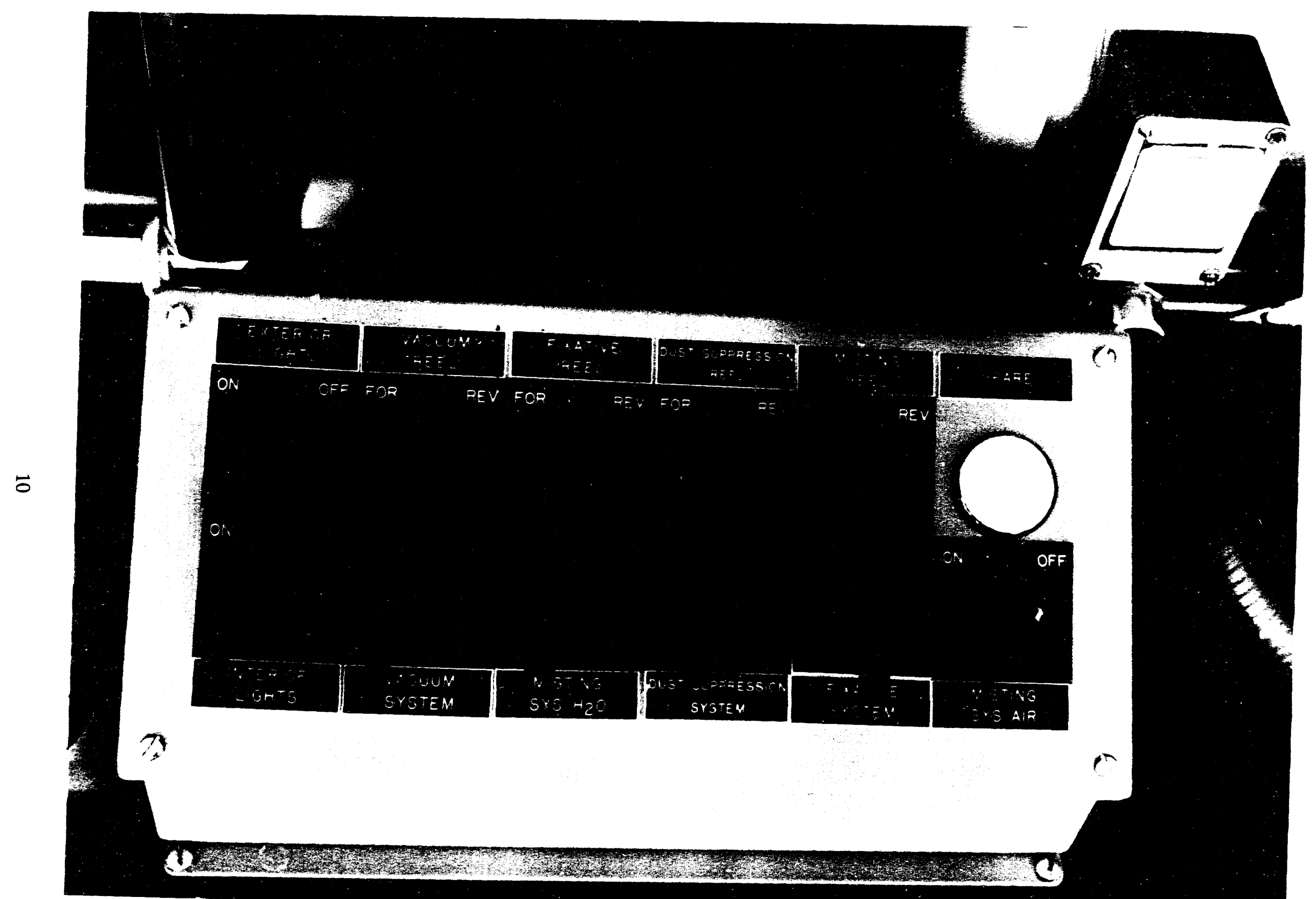

Figure 4. Control panel for the CCU. 
regulator and are then diverted to the misting heads (see Figure 5). The operator then turns the heads off and on as needed at the manifold (or at the trailer control panel, if desired). Air and water hoses are connected from the manifold, via quick disconnects, and routed to the misting heads (see Figure 6). When misting operations are completed, the air and water lines can be disconnected from the spray manifold and the supply lines payed back into the hose reel.

\subsection{Soil Fixative (3M Foam) Application System}

\subsubsection{Description of the Soil Fixative Application System}

The soil fixative application system uses a soil fixative (3M Foam products) that is mixed with water via a "blue box" mixing apparatus shown in Figures 7 and 8 . The function of this product is to provide a long-term, vapor suppressing foam for covering uneven contaminated soil (e.g., steep sloping digfaces) that has a relatively long life, depending on local environmental conditions, if left undisturbed. The chemical constituents, the FX-9161 foam stabilizer and FX-9162 foam concentrate were procured from the $3 \mathrm{M}$ Company.

The product was mixed and applied using the Model 80 3M Foam application system (bluc box) manufactured by Williams Fire \& Hazardous Control. Inc. This system and product was tested to satisfaction during FY-92. The Model 80 or blue box foam application system is specially designed to mix water, the FX-9162 foam concentrate, and the FX-9161 foam stabilizer in the proper proportions (6\% FX-9161, 6\% FX-9162, and $88 \%$ water) to create a pale yellow foam material that is dispensed using volume expansion nozzles.

The blue box is a hand carried unit that is placed outside, near the area to be sprayed. Currently, the fixative application system is designed to operate with approximately $100 \mathrm{ft}$ of $11 / 2$-in. hose on the trailer hose recl. This hose connects to the inlet side of the blue box. On the outlet side of the blue box, the $11 / 2$-in. discharge hose is connected to the volume expansion nozzle. The maximum length of discharge hose is $100 \mathrm{ft}$ based on the current water pressures to the blue box. However, the discharge hose used for these evaluations was approximately 20 -ft long.

The foam concentrate and foam stabilizer hoses extend from the blue box and are placed in their respective pails. The unit is then ready to operate. When the pump is turned on the water flows through the blue box to the discharge hose creating a venturi effect that draws and blends the $3 \mathrm{M}$ products into the discharge line. When this liquid solution encounters air at the expansion nozzle, the solution immediately turns to foam. In seconds, the foam will begin to set up as an effective fixant.

The system must be flushed after each use to prevent the matcrial from solidifying in the blue box and the discharge line and nozzle. It is important to note that the mixed foam begins to cure immediately and will be set up within 30 to 90 seconds.

The FX-9161 stabilizer is known to contain toluene diisocyanates (TDIs). TDIs are an extremely hazardous material to a small percentage of people. Therefore, extreme caution and protection were taken when dispensing and handling this product. All personnel performing $3 \mathrm{M}$ Foam applications wore Class $A$ bubble suits combined with self-contained breathing apparatus 


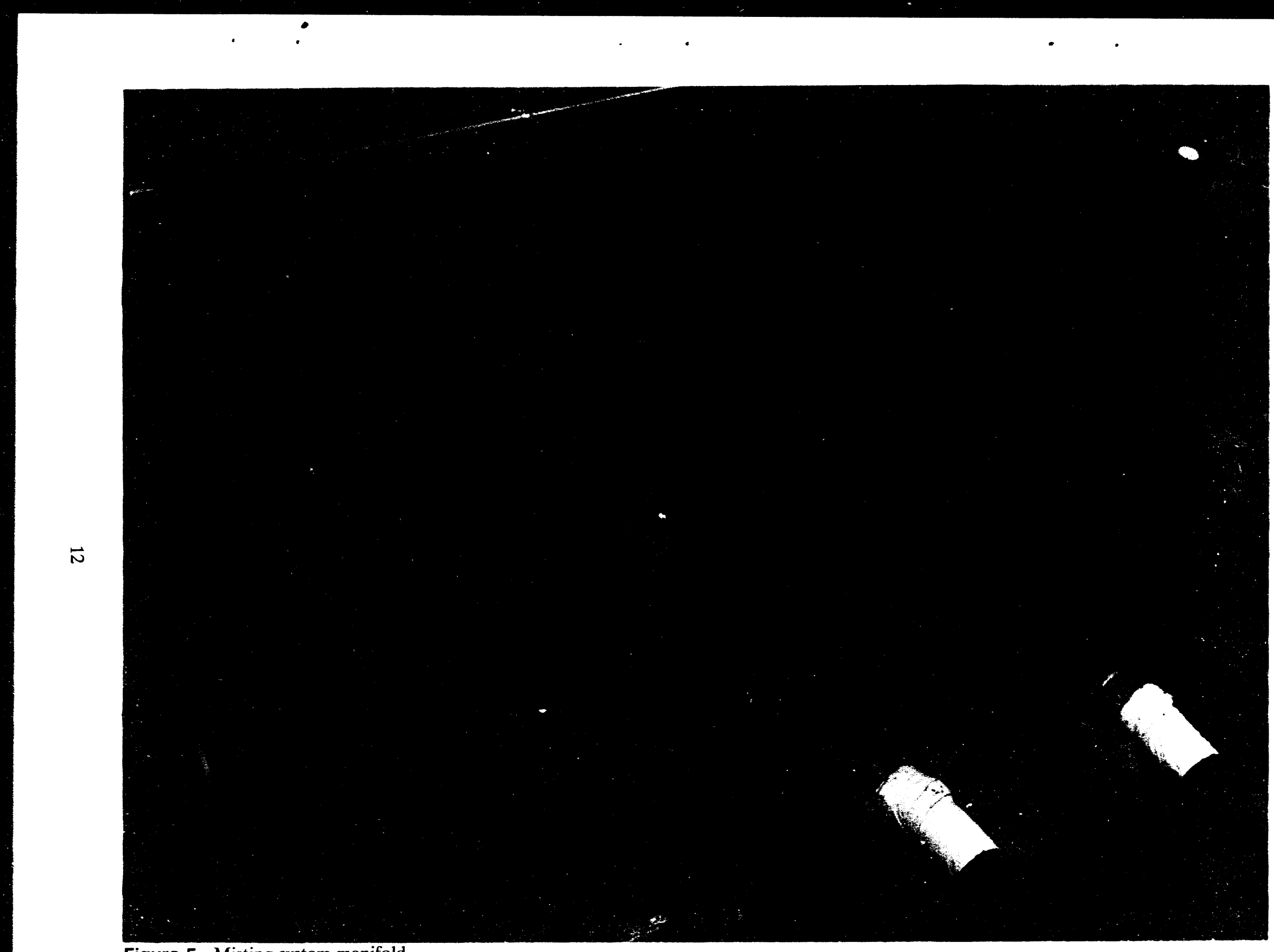




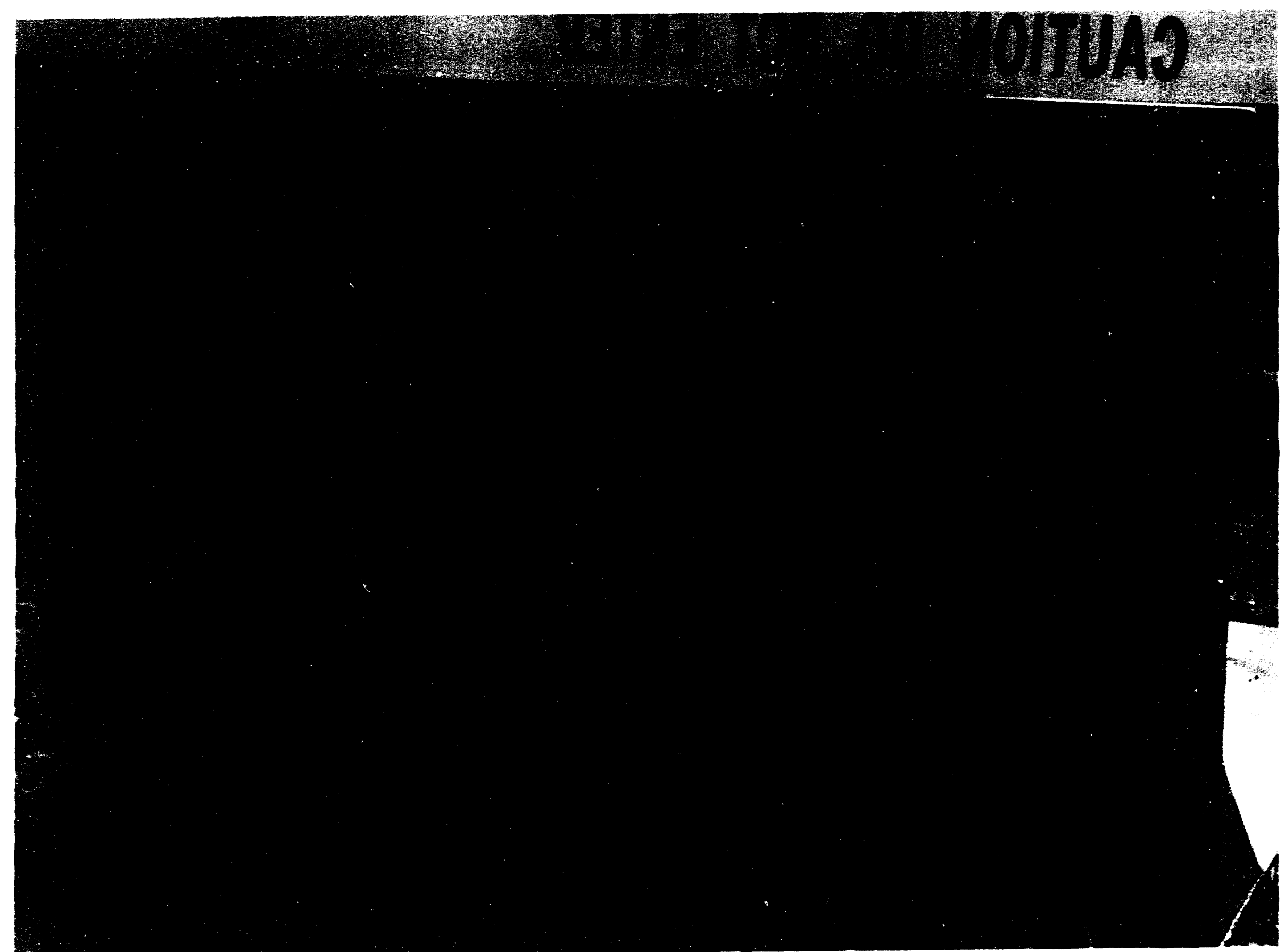

Figure 6. Quick disconnect hose attachments from the manifold to the misting nozzles. 


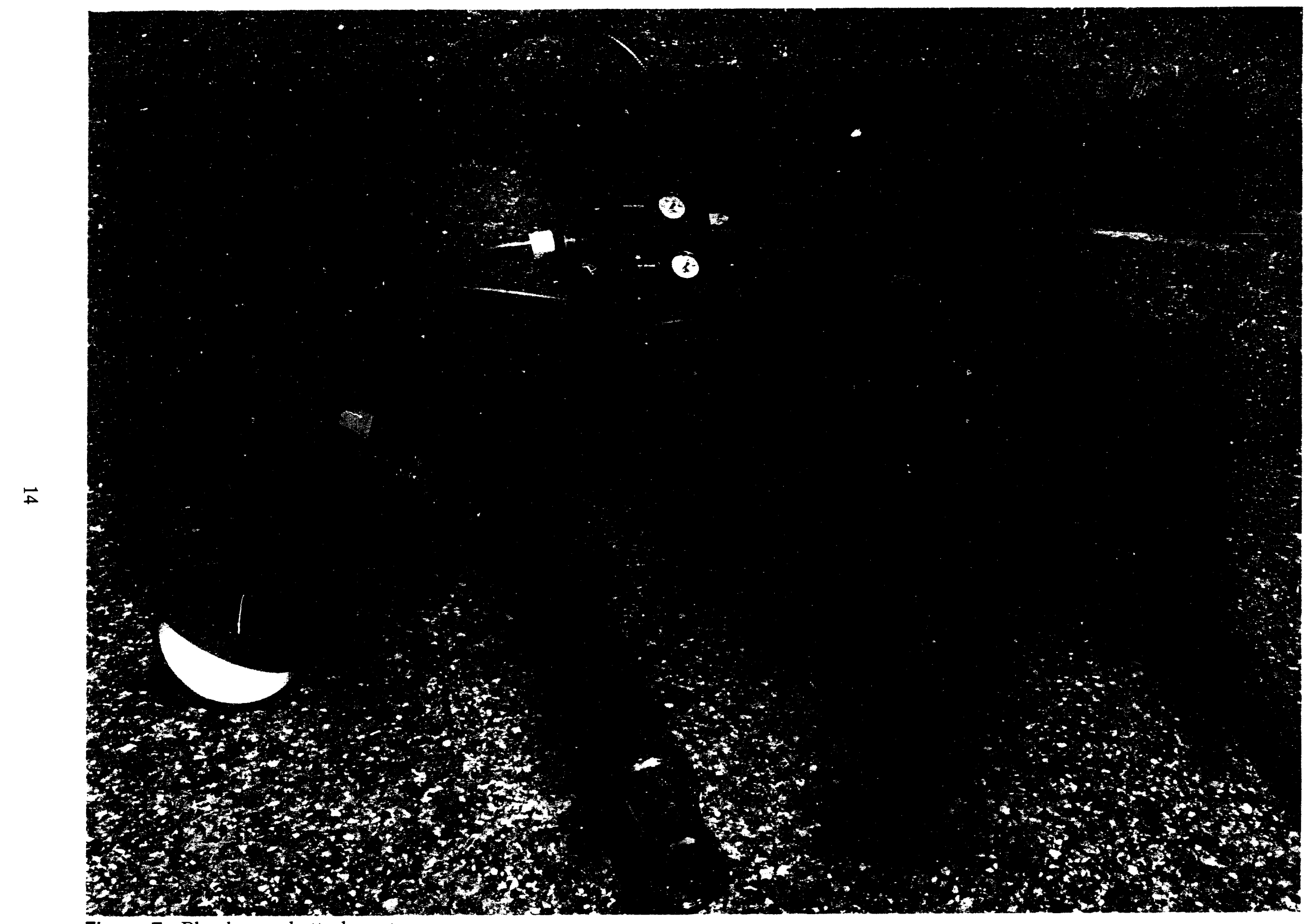

Figure 7. Blue box and attachments. 


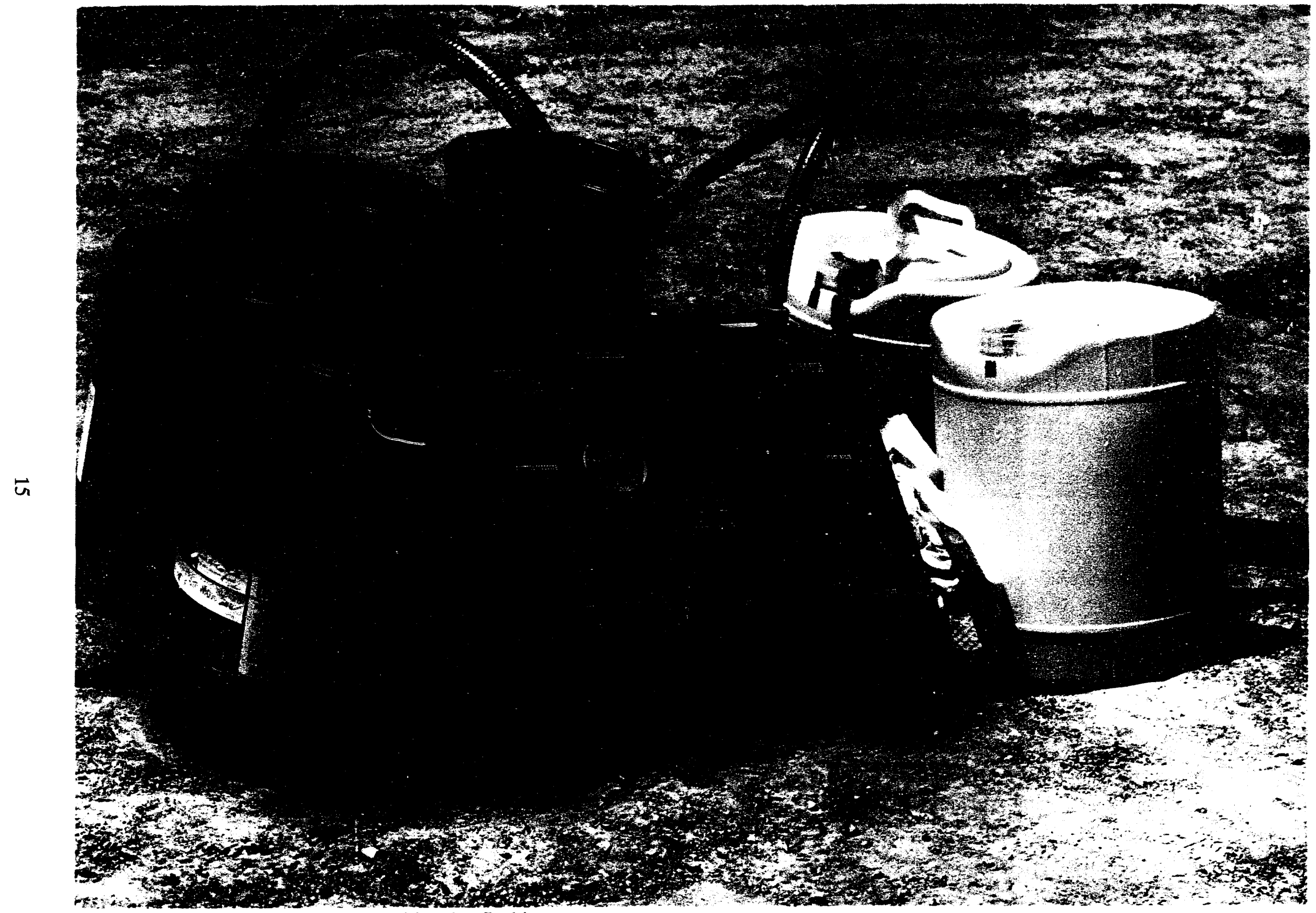
Figure 8. Blue box product hose position for flushing. 
(SCBA). It has finally been determined by EG\&G Idaho Industrial Hygiene that Class B suits with SCBA can be used if the suit material is constructed of butyl rubber or 23 sarinex. Once the foam is exposed or mixed with air and water, the product becomes benign within a few seconds.

All waste from 3M Foam application can be disposed of in the sanitary landfill. Remaining product in the FX-9161 must be neutralized with water before disposal.

\subsection{Dust Suppression Application System}

\subsubsection{Description of the Dust Suppression Application System}

The dust suppression application system is the simplest, yet the most versatile system contained on the CCU because any type oi dust suppressant, surfactant, or fixative (also known as a crusting agent) that solubilizes readily with water can be used with this system. The system consists of a 300gal tank to hold the premixed product, a pump and motor, and a hose and spray nozzle. The product can be suctioned from its container (typically a 55-gal drum) and fed into the water tank using the dust suppression pump, poured directly into the top of the water tank, or pumped into the water tank from an external source (e.g., a railcar tank with its own pump). Previous studies conducted at the INEL evaluated several dust suppressants for application in the CCU.'

The system is operated first by premixing the product in the dust suppression water tank (see Figure 9). The application hose and spray gun or nozzle (see Figure 10) is payed out from the hose reel to the application area, and the pump is turned on. The product is mixed and applied according to the manufacturer's specifications or as needed. When application is completed, the system must be flushed. After flushing the system, the pump is turned off, and the hose is payed back onto the hose reel.

The products tested by the dust suppression system for this report included Wen-Don, Flambinder, and XDCA. All three of these products are nonhazardous, and the empty 55-gal drums can be disposed in the sanitary landfill. None of these products generate waste that must be handled at a later time; the Flambinder (calcium lignosulfonate) and XDCA (sugar beet polysaccharide) are water soluble and over time will percolate or wash into the soil from rainfall. Wen-Don will break down immediately from any foot or vehicular traffic and will deteriorate after a few months outdoors with no traffic.

\subsection{Vacuum System}

\subsubsection{Description of the Vacuum System}

The vacuum system in the CCU is a nuclear-grade, high efficiency particulate air (HEPA) filtered system. The vacuum system, Model DC 5500), is a 5 to $7.5 \mathrm{~kW}$, two-stage system manufactured by Transmatic, Inc. (see Figure 11). The vacuum system provides a means to rapidly decontaminate equipment, personnel, and work areas. The vacuum system is also capable of removing loose particulate debris including small particles in the micron range up to large debris $1.5 \mathrm{in}$. in diameter. Heavy items such as rocks will be limited to approximately $3 / 4 \mathrm{in}$. so that the denser material will still be able to flow from the nozzle to the debris container without lodging in the hose 


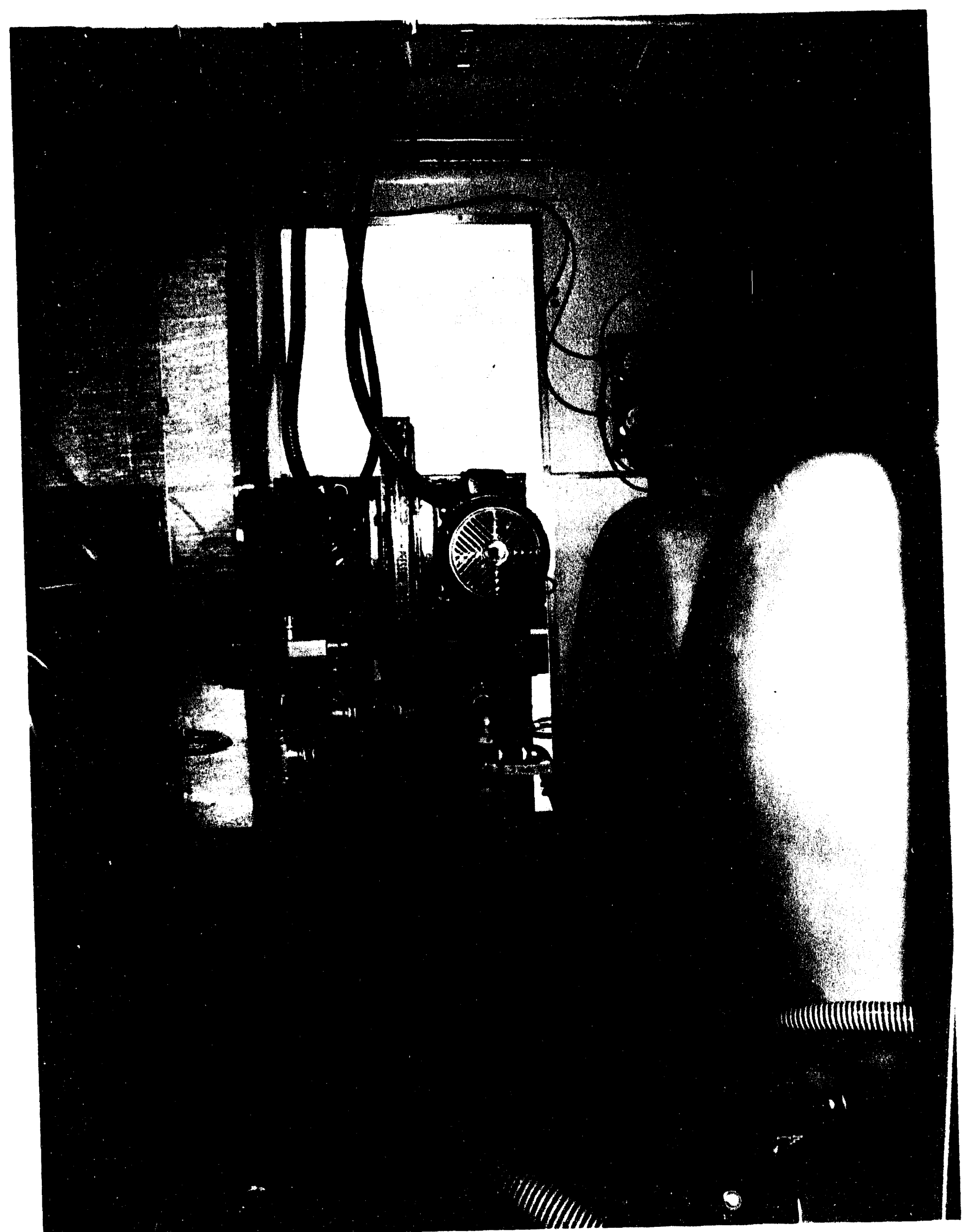

Figure 9. Dust suppression and misting motors and pumps. 


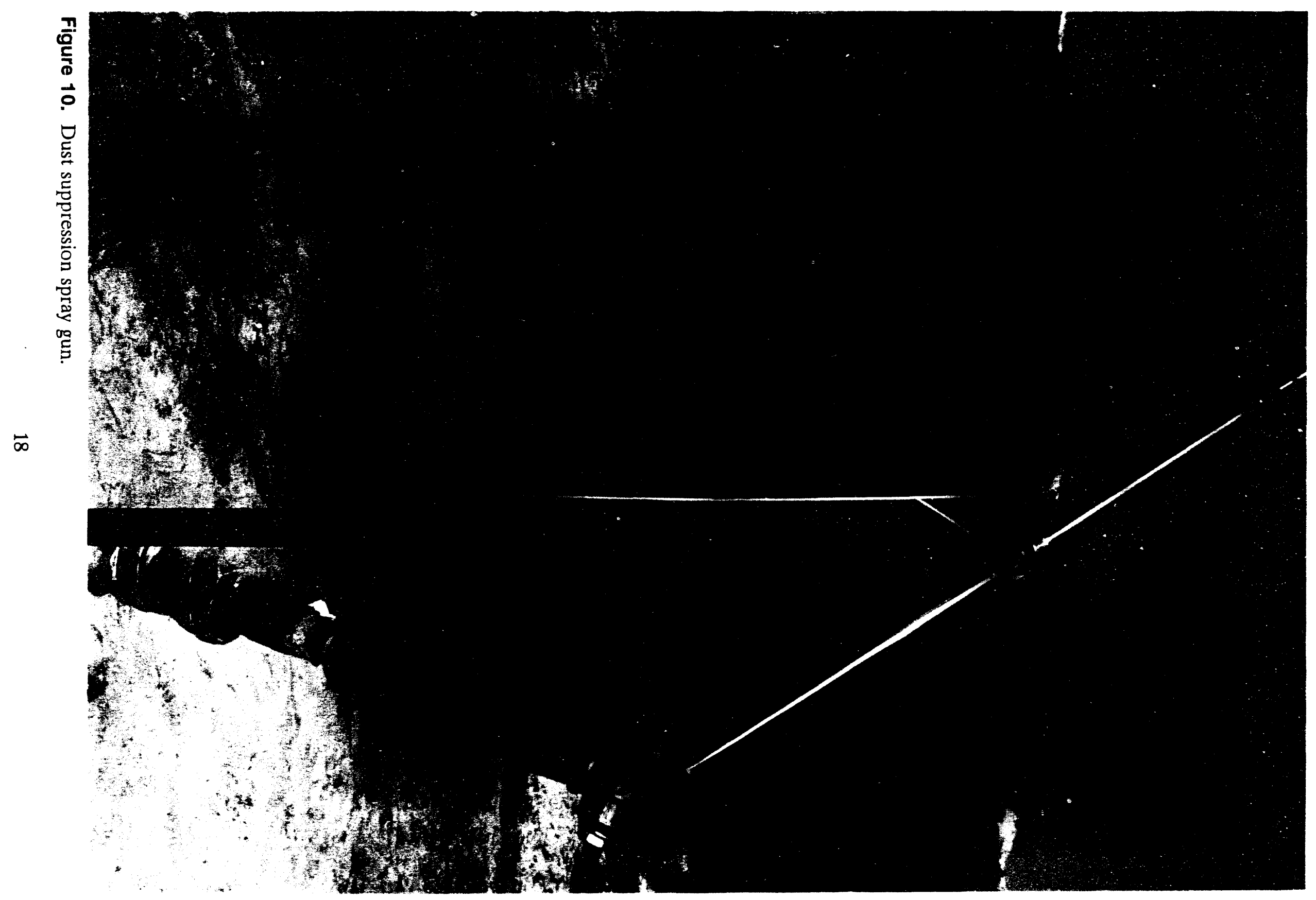




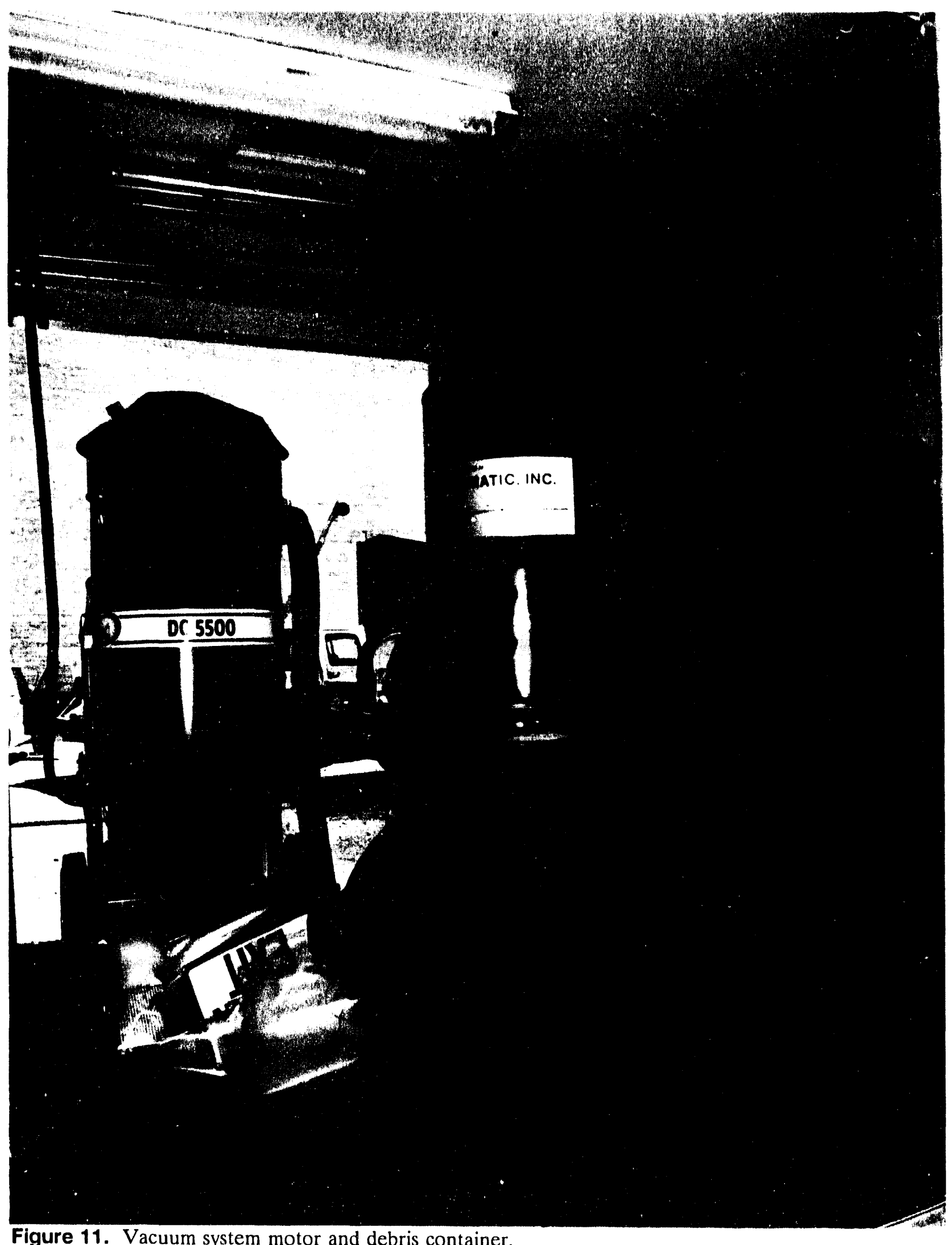

Figure 11. Vacuum system motor and debris container. 
line. The system includes a HEPA liller and a 55 -gal debris container. The container can be changed out when full and replaced with any standard $55-$ gal drum. The full drum can then be properly sealed for final disposal. Because of the limited space in the CCU trailer, moving a lull drum will be difficult. It is anticipated that the drum will be replaced while it is still mancuverable (however, this goes against waste minimization principles), or the hose from the vacuum to the drum will be extended so the debris drum can be placed outside of the trailer on a pallet. There is no mechanism to determine how much dust and debris are deposited into the drum other than by checking the weight of the drum.

The system is operated by turning it ofl and on as needed. The vacuum hose can be payed in or out from its hose reel located at the rear of the trailer. Attachments may be used with the hose as needed to perform the job. 


\section{DESCRIPTIONS OF DEMONSTRATICNS}

Demonstrations and experiments used to test the capabilities of the CCU were conducted in three stages. The tïst stage involved laboratory performance testing; the second stage was a field application for the Environmental Restoration Program involving spraying of a dust suppressant or encapsulant (Wen-Don) and spraying the fixalive 3M Foam; and the third stage was a complete field demonstration of all systems during a simulated, huried waste retrieval demonstration.

\subsection{Stage 1}

Performance testing of the $\mathrm{CCU}$ at a fixed laboratory was conducted to evaluate operational parameters for each system (using only water) to make any needed system modifications and to collect information for writing a draft operations manual for the CCU. ${ }^{5}$

The bubbler sysiem incorporated in the CCU indicates water levels in each of the 300-gal tanks (sec Figure 12). The bubbler system also has sensors activating an audible alarm when the water drops to a preset critical level (for the fixative/misting water tank). The critical level was established to provide adequate water for llushing of the fixative system. This sensor setting was approximated in Stage 1 testing and adjusted in Stage 2. The bubbler system also has a sensor for each water tank to automatically shut off the motors driving the dust suppression and misting/fixative pumps when the water supply levels near empty (to prevent damage of the pumps by pumping air). These sensors were set in Stage 1 and have not needed adjusting.

Preliminary testing of the CCU was done to check the operability and installation integrity of each system. Tests were performed for the $3 \mathrm{M}$ Foam system and the dust suppression system using water only. The misting and vacuum systems were tested as designed. The vacuum system was also performance tested separately by the vendor, and it was demonstrated that the vacuum could remove $\mathrm{I}$ in. of debris using 100$) \mathrm{ft}$ of hose.

Modifications were made and adjusted to optimize the operational characteristics of each system. Pressure levels to the hoses were adjusted, the proper nozzles for soil fixative and dust suppression systems were determined, and water-to-air ratios in the misting system were adjusted to estimate the best dust suppression capability and contamination control possible. In the CCU, there are several gauges and sensors to indicate proper operational parameters. The gauges for water pressure and air pressure were optimized, the adjustable settings locked in place, and the gauge readings noted in the CCU logbook and operations manual. ${ }^{5}$ The blue box (see Section 5.1.2) has two pressure gauges for inlet and outlet water pressures. These were calibrated and set by the manufacturer specifically for the use of $3 \mathrm{M}$ Foam and stabilizer and were not readjusted.

\subsubsection{Stage 1 Testing Setup of the Misting System}

The Dryfog Ultrasonic Misting System was evaluated outdoors at a fixed laboratory. The misting heads were attached side by side to a guard rail 6-ft above ground and positioned approximately $2 \mathrm{ft}$ apart. The initial test consisted of operating the system 10 ensure that the unit functioned according to manufacturer's specifications. The misting system was operated from the controls at the control pancl and from the ball valves at the manifold. 
<smiles>C#CCC(C)(CC=C)CCCC</smiles> 


\subsubsection{Stage 1 Testing Setup of the Fixative System}

Performance testing of the $3 \mathrm{M}$ Foam system was conducted at a lixed liaboratory using water but without product mixed into the system. The trailer was placed outside the laboratory, and power was connected to the generator. The fixative system water lank was filled (approximately 30() gal), and inlet, outlet, and product hoses were connected to the blue box. The low-volume expansion nozzle (red) was connected to the discharge hose. The product hoses extending from the blue box were placed into buckets of water to simulate suctioning foam products. The pump was turned on and the system started. The start time of the pump and the inlet and cullet pressures were noted in the project logbook. When the tank was near empty, the sensor activating the automatic pump shutoff was adjusted. The pay-out and pay-in capabilities of the hose reel were evaluated to determine the safety requirements for using the hoses associated with this and other systems.

\subsubsection{Stage 1 Testing and Setup of the Dust Suppression System}

Performance testing of the dust suppression system was performed outdoors at a fixed laboratory. Water only was used in these tests to evaluate the overall performance (i.e., spray characteristics, line pressures, regulator settings, and flow rates) of the system. ensure the system functioned according to design specilications, and determine if any necessary modifications were needed to maximize performance.

\subsubsection{Stage 1 Testing and Setup of the Vacuum System}

The vacuum system was planned to be tested in two stages, the first at the fixed laboratory, the second at the CTP. However, because of high moisture content of the CTP soil (extensive rainfall delayed the project 2 weeks) and the lack of dust generation from various operations, the vacuum system was not needed.

The purpose of testing at the laboratory was to test the basic performance characteristics of the vacuum system and determine if any modifications were needed before moving the CCU to the field for additional operation. The vacuum system required a control panel eperator and vacuum hose operator. The control panel operator was responsible for turning the vacuum system on and off and monitoring the level of the debris canister (catch drum). The vacuum hose operator used the vacuum hose and attachments to perform the operations as required. The following test was performed. A $2 \times 4$-ft test area was covered with an assortment of debris such as small rocks and pebbles, soil, and paper scrap. The control panel operator turned on the system, and the vacuum hese operator attempted to remove all the materials from the test area. The vacuum system was turned off, and the debris canister (catch drum) was removed and emptied.

\subsection{Stage 2}

Performance testing of the CCU dust suppression system was evaluated by spraying Wen-Don during the INEL Environmental Restoration Program's operation that involved encapsulating a slightly contaminated soil area near a decommissioned INEL reactor. In addition, the 3M Foam products were also sprayed to examine the fixative system and ensure that it was operating properly with the actual product. This information was also incorporated into the draft CCU operations manual. ${ }^{5}$ The misting and vacuum systems were not tested at this time. 


\subsubsection{Stage 2 Testing and Setup of the Fixative System}

The spraying of $3 \mathrm{M}$ Foam was not part of the support effort to control contaminated soil in areas near the INEL decommissioned reactor. This was merely an opportunity to perform tests identified in the test plan in an appropriate spray area using actual product.

Testing actual products and flushing were the only tests performed because of time limitations and available personnel (this had to be done during the down time for the contaminated soil spraying task). The flush test determined the total amount of time and water that was needed to flush the system. This test enabled the audible alarm sensor to be set for the low-water level limit of the supply tank. Once foam was spraying from the nozzle, the control panel operator noted the tank level and time, then asked the blue box operator to put the foam system into the flush mode. When water was flowing through the volume expansion nozzle, the system was shut down. The audible alarm sensor was adjusted to a water level 1.5 times the amount of water needed for flushing. If and when the 100-ft discharge hose is used. the alarm sensor will have to be readjusted to compensate for the longer hose.

\subsubsection{Stage 2 Testing and Setup of the Dust Suppression System}

The dust suppressant Wen-Don CPB-12 was sprayed in three contaminated soil areas near a decommissioned reactor building covering approximately $70,000 \mathrm{ft}^{2}$. This contamination control project provided valuable experience and was the first attempt with the $\mathrm{CCU}$ at using actual contamination control products on a contaminated site.

Because the objective of this project was to provide control (encapsulation) of contaminated soil using an untested product, there were only two test objectives: performance evaluation of the dust suppressant system and evaluation of the Wen-Don product.

\subsection{Stage 3}

Stage 3 was a full-scale field test of each system using actual contamination control products at the CTP. The purpose of the Stage 3 tests was to evaluate each system in an operational cnvironment, determine the best operational parameters for each system (e.g., pressures, flows, and mixing), evaluate contamination control products, and acquire operational experience and knowledge to incorporate into the linal CCU operations manual. The first draft of the operations manual was used to support the Remote Excavation System (RES) field demonstration at the CTP.

The CCU was used to support a simulated TRU buried waste retrieval demonstration, called the RES demonstration, which was conducted by BWID during the summer of 1993. The purpose of this demonstration was to test and evaluate the operational characteristics of a robotic, remote controlled, excavation vehicle. As part of this demonstration, the CCU was used to provide contamination control services in a noncontaminated environment. The purpose for providing this service was to test the CCU in an operational mode during actual retrieval operations.

The RES demonstration was conducted inside an $86 \times 64-\mathrm{ft}$ tent to simulate an actual retrieval eflort with minimal weather effects. The CCU was tested using the dust suppression agents on vehicle traffic surfaces and the misting system and soil fixatives over the excavation and dumping 
areas. Air particulate samplers were used to measure the particulate dust concentration around each pit where these products and/or systems were employed. The samplers were placed as close lo each cell as possible without interfering with the misting heads or the excavation vehicle. Filter samples were taken both with and without the CCU systems or products employed in order Io evaluate the relative performance of these systems in a lull-scale operation.

The retrieval cell of the CTP was divided into four waste zones or cells. Each waste zone was divided in half, one half used contamination control support and one hall had no support. Afler the overburden was removed, the excavation vehicle was positioned over the lirst waste cell and retricval operations began on the first half of the eell where no contamination control support was provided. After the first half of the waste cell was cleared, the vehicle was positioned over the next half eell. Contamination control support was established using $3 \mathrm{M}$ Foam or potato starch on the cell digface, depending on which cell was being excavaled, and the misting system was used during the excavation and dumping operation.

\subsubsection{Stage 3 Testing and Setup of the Misting System}

The misting system was used in conjunction with the 3M Foam system and potato starch application to control fugitive dust generation over the excavation and the dumping area of each cell. Two misting heads were placed onto stands that extended 3 fit over the excavation area and were pointed in a 30 to 45 degree angle down toward the digging surface (which was 6 to 12 fi below). The misting heads were positioned on the same side but at opposite ends of the excavation area during the excavation of Cell 1. During the excavation of Cells 3 and 4 , the misting heads were located on each side of the excavation area (sec Figure 1.3) (see Figure A-1 in Appendix A). Two) more misting heads were placed onto 6-ft stands over the waste box and were pointed in a 0 to 30 degree angle down toward the soil surface. The misting heads were positioned opposite each other at each end of the waste box.

The misting performance was evaluated using $47-\mathrm{mm}$ air particulate samplers placed adjacent to the digging and dumping area where there was no interference with the misting heads/spray or excavation operations.

A series of digging operations was performed on the lirst half of the first waste zone without contamination control to establish a bascline air to dust concentration. The sampler filters were collected after the waste zone was cleared of waste but before the excavator was moved to the next half of the zone.

When the first half of the waste zone was excavated, another duplicate series of digging operations was performed with contamination control using the misting system and soil fixative system (3M Foam or potato starch). The sampling positions were duplicated as closely as possible over each waste zone. New filters were placed back into the sampler holders before the excavation began. The particulate filters were collected after the excavation operation, and the results were compared to the baseline concentration. Comparisons of dust mass determined a dust control factor and a dust control efficiency for the tests in this operation. The results of these tests were used fo determine the effectiveness of using low-volume misting in a large scale excavation and retrieval operation. Data from these tests are listed in Table 1 in Appendix $A$. 

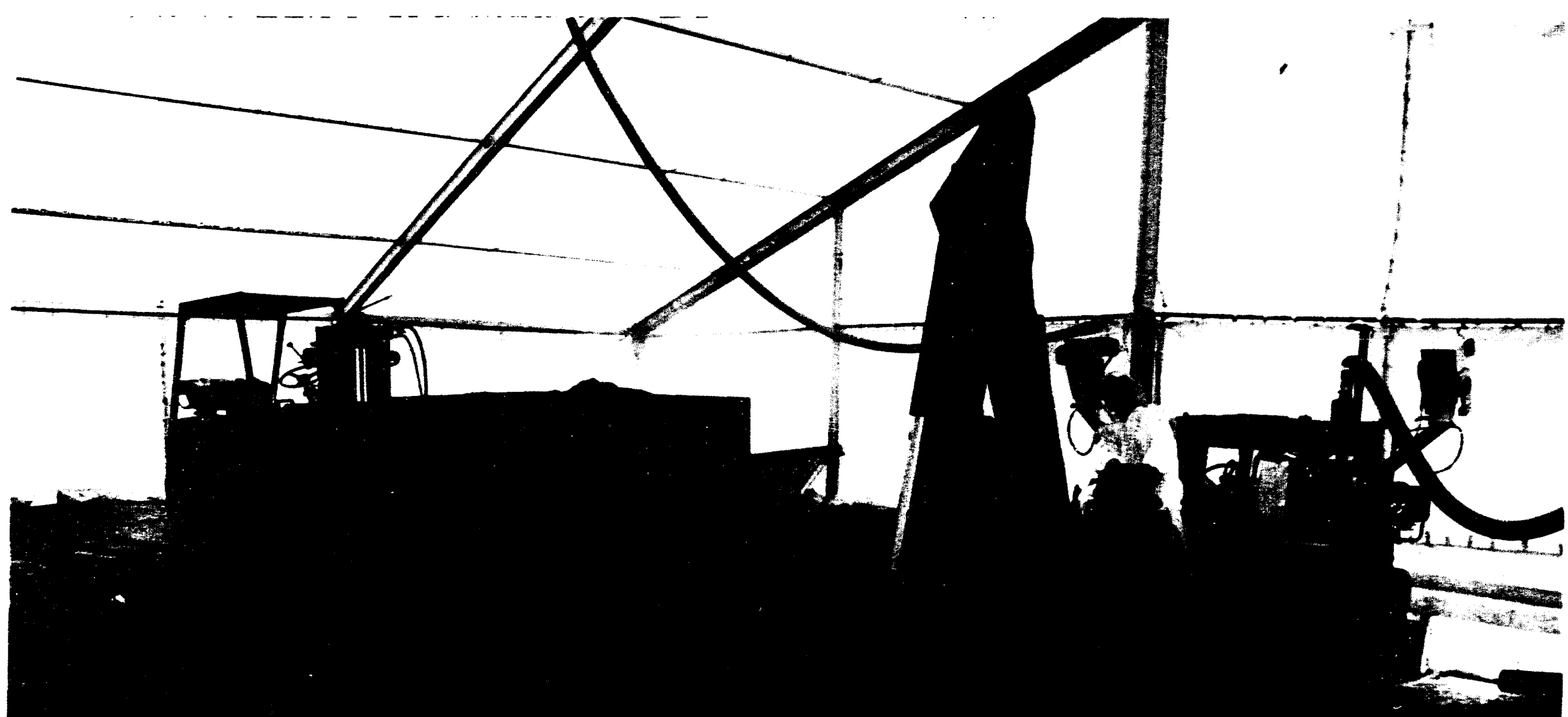

Figure 13. CCU misting during Cell 3 excavation. 
The project scientist reconfigured the misting head locations when necessary to maximize the system performance. Misting operations were performed over three of four waste zones. The misting system was turned on only while digging operations were heing performed and turned off when the operations were completed. Efforts were made to duplicate or repeat the same number and types of operations performed during the excavation. For example, in Cell 3, six drums were excavated with no contamination control, and six drums were excavated with contamination control. Similarly, the same number of scoops of soil was removed by the RES for each side of the cells or zones.

\subsubsection{Stage 3 Testing and Setup of the Fixative System}

The system was tested at the CTP on two occasions: lirst, outdoors on the east face of the pit and second, indoors on Cell 4 during the RES demonstration.

Because the area to spray in Cell 4 was small $(5 \times 10 \times 10 \mathrm{ft})$, the first objective of spraying the east face of the pit was to determine the minimum amount of coverage this system would permit. In other words, the system was turned on and the nozzle operator waited until foam was dispensed. As soon as foam was emitted from the nozzle, the llushing procedure began. The nozzle operator sprayed an area until water was emilted from the nozzle, then the operator sprayed away from the cast face to a designated flush area. At this time, the system was shut off. The test was done with both the low and high volume expansion nozzles for comparison. The area covered with foam was determined to be the minimum spray area.

The second objective of spraying the east face of the pit was to determine the maximum spray area. The purpose of the maximum coverage test was to determine the size of the spray area that could be obtained from one 300 -gal water tank. This included determining the total square feet of foam coverage, amount of foam stabilizer and foam concentrate usage, average foam depth, and the operation time before flushing became necessary.

When the 3M Foam system was turned on, the control panel operator noted the on-time in the project logbook. The spray operator directed the foam over the premarked application area of the east face and covered it with foam at an average 1 -in. depth (as suggested by the manufacturer for the best curing thickness) until the minimum llush level of the supply tank was reached. When the low water alarm sounded, the off time was recorded, and the system was llushed. As soon as the unit was flushed, the system was shut down, and the equipment was cleaned. The coverage areal and foam depth were measured. The foamed area was allowed to cure to a iirm consistency.

The third objective of spraying the east face of the pit was to experience the new personal protective equipment requirements for $3 \mathrm{M}$ Foam. After spraying foam in Stage 2, it was determined that Class A bubble suits and SCBA would be worn in the future. Spraying the east face gave the operators experience and practice that proved beneficial for spraying Cell 4.

The 3M Foam product was also used on the contamination control side of Cell 4 to fix and stabilize the digface surfaces. After the lirst half of Cell 4 was excavated, the $3 \mathrm{M}$ Foam was applied to the remaining dig area of the waste zone. This area was covered with one or $\mathrm{mo}$, re inches of foam to ensure proper coverage. When the foam was properly applied, the system was flushed and shut off. The foam cured for 5 minutes before misting and digging operations resumed. The foam was 
reapplied at regular intervals as more and more untreated soil became exposed, until the digging of Cell 4 was completed.

During digging operations, the foamed areas were closely observed to determine the breakaway characteristics of the foam during digging operations and how much the foam stuck to the digging equipment.

\subsubsection{Stage 3 Testing and Setup of the Potato Starch System}

This product is the only product evaluated that did not use the systems in the CCU. When initial testing began, a 25-gal portable tank and sprayer was used to dispense the product. The dry potato starch came in 50-lb bags and had a granular consistency similar to sand. This material is a pregelled (previously hydrolyzed, then dried or freeze-dried), food grade, unmodified starch product.

This product was tested on several occasions at the CTP. Outdoors, there were two different applications on loose soil digfaces with approximately 45 degree slopes and one application on a flat, low traffic area. Indoors, there were several applications completed on vertical soil digfaces during the simulated TRU buried waste retricval demonstration or the RES demonstration.

\subsubsection{Stage 3 Testing and Setup of the Dust Suppression System}

The dust suppressants tested at the CTP were Flambinder (calcium lignosulfonate) and XDCA (a sugar beet polysaccharide). They were chosen because of their ability to work well on INEL soils and their environmental acceptability. The use of polysaccharides was in support of a Westinghouse Hanford Site work package sponsored by BWID. After the initial testing at the CTP, the Flambinder and XDCA were then sprayed on the traffic areas on each side of the retrieval cells during the RES demonstration.

Since Flambinder works best on premoistened soil, its test area was sprayed with water from a water truck before spraying the product. XDCA was tested with and without prewetting the application area. The dust suppression system required a control panel operator and a spray nozzle operator. Testing of Flambinder and XDCA were performed on the application area as follows. The spray nozzle operator began to coat the premoistened application area with the product at the rate of $1 \mathrm{gal} / \mathrm{yd}^{2}$. When the supply tank emptied or when all applications of a particular product were completed, the supply tank was filled with water, rinsed, and the rinse water flushed from the system. The product on the application area was allowed to cure, and the cure time was noted in the logbook. Each product was reapplied at a rate of $2 \mathrm{gal} / \mathrm{yd}^{2}$ to compare suppressant quality and characteristics.

After this initial test was completed, other areas of the CTP were treated with Flambinder and XDCA, which provided additional operational experience and dust control for the RES demonstration project. 


\subsubsection{Stage 3 Air Sampling Systems}

A total of 10 low-volume air samplers collected dust loading on filters at strategically located positions surrounding the digging and dumping area. Figure 14 shows an example of air sampler placement. A baseline dust loading was established for each excavation campaign by excavating without contamination control being applied and by comparing the bascline to dust loading during excavation.

5.3.5.1 Using Contamination Control Applications. Appendix A contains the air-sampler filter dust loadings obtained during the experiments. A control efficiency is calculated for each filter for each campaign, and a control factor is evaluated. The control efficiency is the dust loading per volume of sampling air (concentration) with no contamination control (baseline) minus concentrations with contamination control divided by the bascline concentration times $100 \%$. A control factor is also calculated, which is a simple ratio of the bascline concentration divided by the contamination control concentration. For example, if the control efficiency is negative, there is an indication of poor control. If the control factor is greater than one, there is an indication of a positive contamination control result. Appendix A lists control efficiencies and control factors for three separate excavation campaigns, which represents digging and dumping in different zones of the CTP. 


\section{CELL 1 EXCAVATION SETUP}

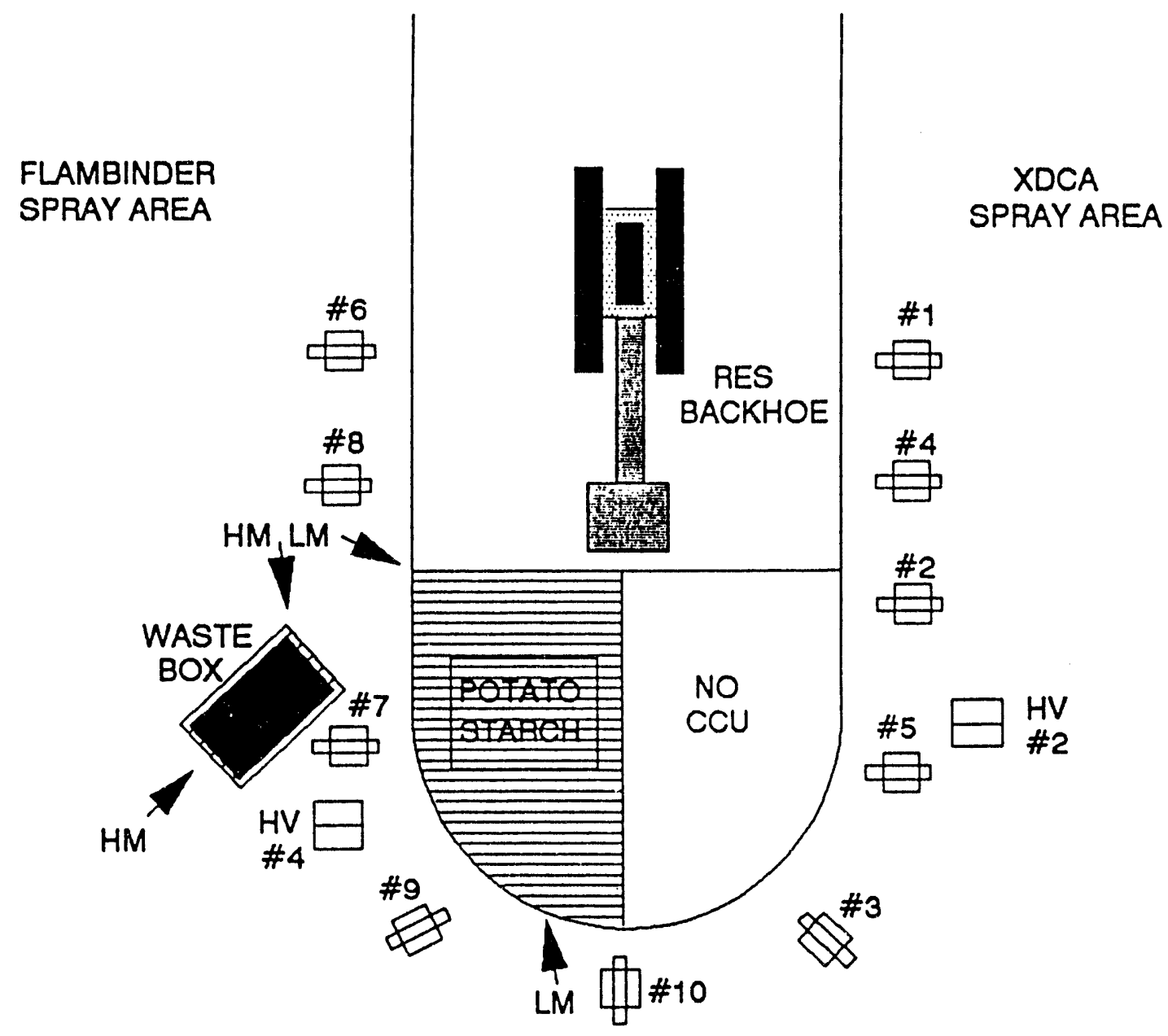

$$
\begin{aligned}
& H M=\text { HIGH STAND MISTER } \\
& \text { LM = LOW STAND MISTER } \\
& \square=\text { LOW-VOLUME SAMPLER } \\
& =\text { HI-VOLUME SAMPLER }
\end{aligned}
$$

Figure 14. Cell 1 excavation setup. 


\section{DEMONSTRATION RESULTS}

The following results were obtained during Stage 1, 2, or 3 testing.

\subsection{Stage 1 Results of the Misting System}

Overall, the misting system worked as expected. Several leaks were detected in the system and repaired. The regulator settings at the manifold were adjusted to $70 \mathrm{psi}$ for air and $10 \mathrm{psi}$ for water. At these settings, each misting head used approximately $1 / 2$ gal of water per minute. The water regulator was adjusted to 20 psi to increase the water-to-air ratio, which consequently altered the water consumption to approximately 1 -gal/minute. The range of spray for each misting head was approximately $5 \mathrm{ft}$ in distance and $3 \mathrm{ft}$ wide before the mist began to disperse. Wind had a significant influence on the performance of the misting system causing the mist or fog to be easily misdirected or distorted.

\subsection{Stage 1 Results of the Fixative System}

The initial testing at the laboratory (using water only) showed that the fixative pump pressure regulator had to be adjusted to make the inlet water pressure $125 \mathrm{psi}$. The 300 -gal water tank was emptied in approximately 5 minutes. The sensor to activate the automatic pump shutoff worked as expected. The low water alarm sensor was adjusted so it would signal when 140 gal remained in the water tank. The sensor was adjusted for more accuracy when actual 3M Foam was tested in Stage 2. Water was propelled approximately $40 \mathrm{ft}$ from the low-volume expansion nozzle (red) and $15 \mathrm{ft}$ from the high volume nozzle (blue).

The fixative hose reel was tested and found to operate as expected. However, as the nozzle end of the hose neared the reel, it became necessary to reel it in cautiously to prevent any whipping action from injuring the control panel operator or damaging any equipment.

\subsection{Stage 1 Results of the Dust Suppression System}

Several leaks were discovered in the system and were repaired. Pump pressure was adjusted to $100 \mathrm{psi}$. The bubbler system setting for automatic motor/pump shutoff was set to a conservative level of 50 gal remaining in the 300-gal tank. Product suctioning (using water to simulate a product) was tested and proved to work adequately. The spray gun nozzle could regulate the flow from a fine, mist for high spray control to a 60-ft stream for coarse spray control. Flow rates for water were between 10 to $20 \mathrm{gpm}$, depending on whether the nozzle was set for mist or stream application.

\subsection{Stage 1 Results of the Vacuum System}

Initial testing at the fixed laboratory provided enough experience to evaluate the objectives of the test plan. ${ }^{4}$ The vacuum system performed as expected, but the attachments included with the system were not adequate for all applications. An attachment for narrow spaces needs to be added to the system. The system was very capable of picking up paper, soil, and rocks up to 1 in. in diameter using $100 \mathrm{ft}$ of hose. Any dense item vacuumed clanged loudly as it entered the debris container, especially when the debris container was empty. 


\subsection{Stage 2 Results of the Fixative System}

Testing at the decommissioned INEL reactor area showed that it took 1.5 minutes to empty each 5-gal pail of FX-9161 and FX-9162 stabilizer and foamer. When using the 20-ft discharge hose, it took 20 seconds to flush the system. A $15 \times 50-\mathrm{ft}$ area was covered in foam in 1.5 minutes (500 ft/min). These results closely matched the vendor's (Williams Fire \& Hazardous Control, Inc.) specifications. The foam cured enough to provide a proper soil barrier in 20 to 30 seconds. It took 24 hours for the foam to cure completcly leaving an elastic crust $1 / 16$ to $1 / \mathcal{S}$ in. thick.

Since proper flushing only took 20 seconds and used approximately 20 gal of water, the low water alarm sensor was adjusted to 1.5 times the amount of water needed for flushing. In other words, the alarm level of the water tank was changed from the 140-gal mark to the 90-gal mark ( $30 \mathrm{gal}$ reserved for flushing, leaving 60 gal remaining in the tank).

During post-spray cleanup, it became apparent that the FX-9161 stabilizer would not clean up easily. Anything coming in contact with the FX-9161 should be allowed to dry so it can be scraped or brushed off. It will not wash off with water or soap. There were no clogging problems with the hoses, but the FX-9161 did coat the outside of the product hose at the blue box. The outside of the FX-9162 product hose was easily rinsed clean with water.

\subsection{Stage 2 Results of the Dust Suppression System}

Wen-Don had a viscosity similar to vegetable oil and was somewhat difficult to suction into the water tank using the dust suppression pump. Some Wen-Don drums had a film at the top that eventually clogged the spray nozzle. These two conditions caused the dust suppression pump rollers to wear and finally fail. A replacement pump was installed. Because of nozzle clogging, the flow rate and line pressure were significantly reduced (50 to 75\%), degrading spray performance. This was corrected after the completion of the project.

The Wen-Don was diluted with water in a 10-to-1 ratio of water to product. The solution was milky white in color with an odor identical to Elmer's Glue. This mixture behaved more like an encapsulant than a dust suppressant. The product dried quickly after application (the soil was not prewetted) and did not withstand any level of disturbance. Occasional foot traffic over the surface easily destroyed its dust suppressing or encapsulating capability. This product is not recommended for most uses.

\subsection{Stage 3 Results of the Misting System}

Dust loading results of Cell 3 excavation showed a contamination control efficiency of 40 to 83\%, depending on the sampler location (see Table 2 in Appendix A). This efficiency is based on the combination of the misting system and the soil fixative (potato starch) to control the dust generated during the excavation process.

Cell 1 dust loading results were poor. Samplers surrounding the contamination control half of the cell showed a small but positive control efficiency (5 to $36 \%$ ). Samplers surrounding the half of 
the cell without contamination control showed no ability to control dust generation (sec Table 1 in the Appendix A).

Dust loading results of Cell 4 (Cell 2 was not lested) showed no ability to control dust generation (i.e., the control efficiency was negative).

Several factors caused these results for Cells 1 and 4 . The primary factor was that the excavation segment of the BWID project had conflicting test objectives. To meet the objectives of one demonstration constituent, compromised another. For example, the misting spray fogged the RES video cameras. The decision to make digging or contamination control the primary objective had to be made. Consequently, in order for the RES operator to dig remotely, the misting heads had to be pointed in a direction that did not fog the camera. This change in direction grossly jeopardized the efficiency of the misting system. Another example involved removing waste from the excavation area; the RES accidentally dropped waste onto the low-volume air samplers, knocking them over. A decision had to be made to move the samplers farther away from the excavation area or leave them in place. Moving them farther away would have decreased the ability to collect any dust (the soil was already high in moisture content). Consequently, it was decided to leave them in place and continue. This also biased the dust loading results. The sampling and contamination control operations were not permitted to be as rigorous as desired without jeopardizing other aspects of the demonstration.

\subsection{Stage 3 Results of the Fixative System}

\subsubsection{East Digface of the CTP}

Testing 3M Foam on the cast face of the CTP showed the minimum spray area was $8 \times 8$ ft for both volume expansion nozzles; however, the high volume nozzle (blue) covered this area better than the low-volume nozzle (see Figures 15, 16, and 17). The maximum spray area for one 300-gal water tank was determined to be 1,500 to $2,000 \mathrm{ft}^{2}$. This is lower than the vendor's specification because the foam was sprayed on a rough dirt lace with a 45 to 60 degree slope. The vendor's specification was based on a flat surface and did not account for irregular dirt surfaces and some product runoff. Foam did not run off the face unless too much was applied. This occurred when trying to cover the irregular surfaces thoroughly. Excess foam slowly pooled to the bottom of the face. The pale ye!low foam cured in 20 to 30 seconds, the same amount of time as in Stage 2. Measurements of the foam immediately after spraying showed a thickness range of $1 / 2$ to 3 in. This was expected based on the rough physical conditions of the face. Almost exactly 24 hours after spraying the east face, the foam cured completely. The foam was approximately $1 / 16$ to $1 / 8$ in. thick, and it withstood light foot traffic on flat surfaces with no degradation (sec Figures 18, 19, and 20).

FX-9162 foam concentrate was sprayed without adding the FX-9161 stabilizer to evaluate the characteristics of the unstabilized foam (see Figure 21). This test showed that the unstabilized foam produces a protective barrier for short durations. The white foam evaporated and became ineflective after about 20 minutes. This type of spraying will not require bubble suits or SCBA because the hazardous TDIs are in the stabilizer. Spraying foam without stabilizer could prove effective for shortterm contamination control.

Class $\mathrm{A}$ bubble suits and SCBA were used for these tests. Interpersonal communication, heat

stress, and claustrophobia became a concern when spraying the east face of the pit. Some spray 


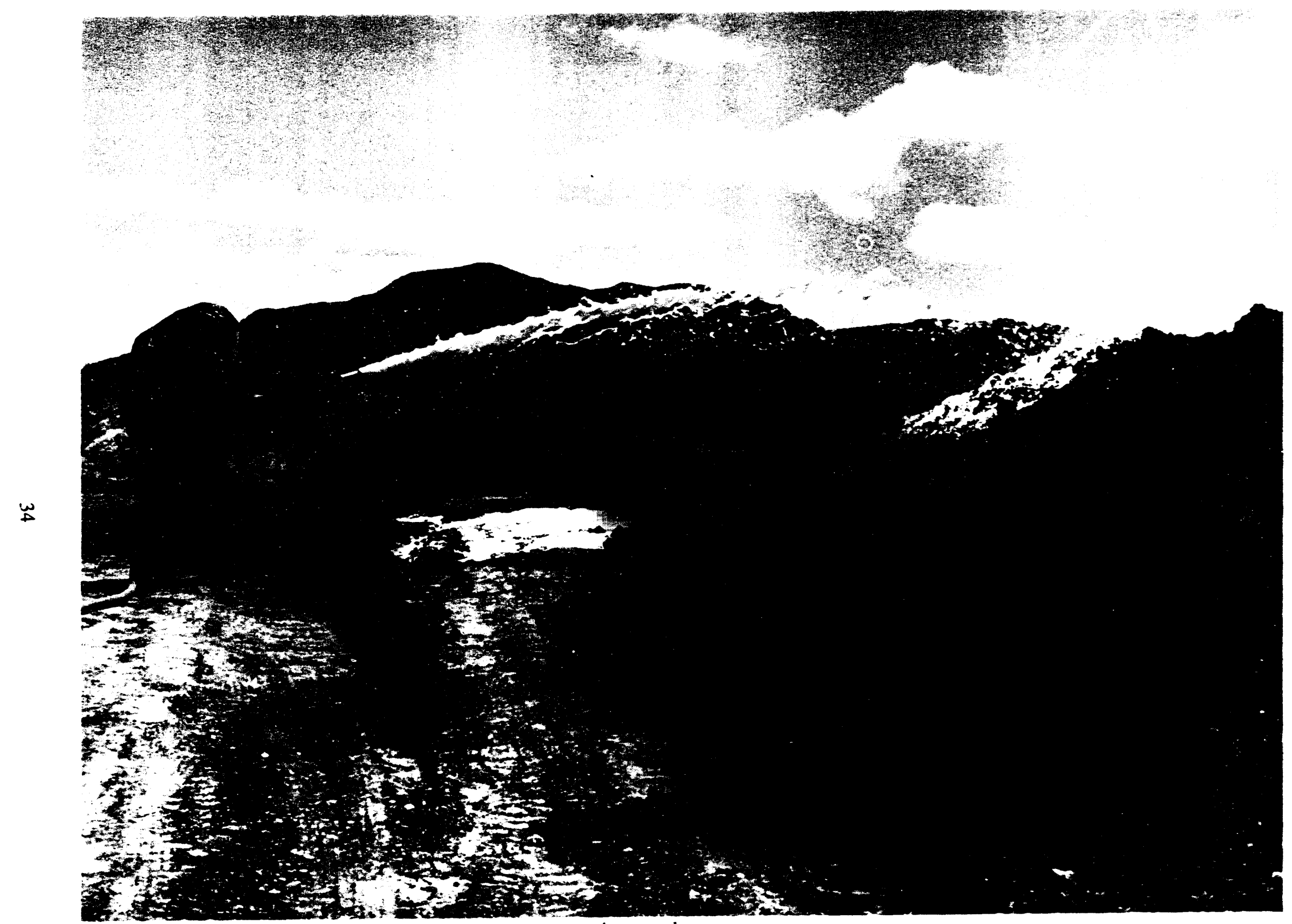

Figure 15. Nozzle operator using the $3 \mathrm{M}$ Foam low expansion nozzle. 


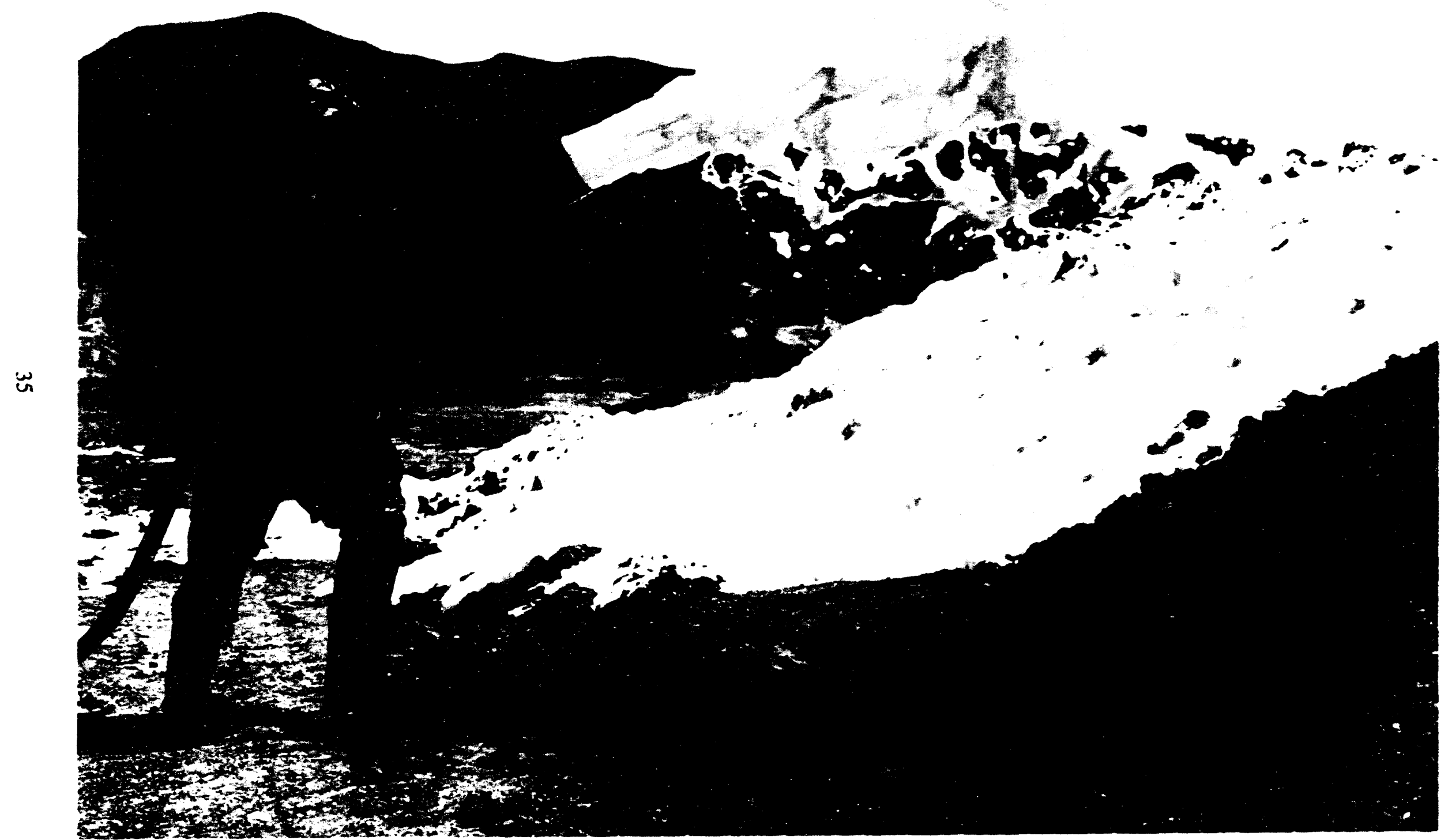

Figure 16. View 1 of nozzle operator using the $3 \mathrm{M}$ Foam high expansion nozzle. 


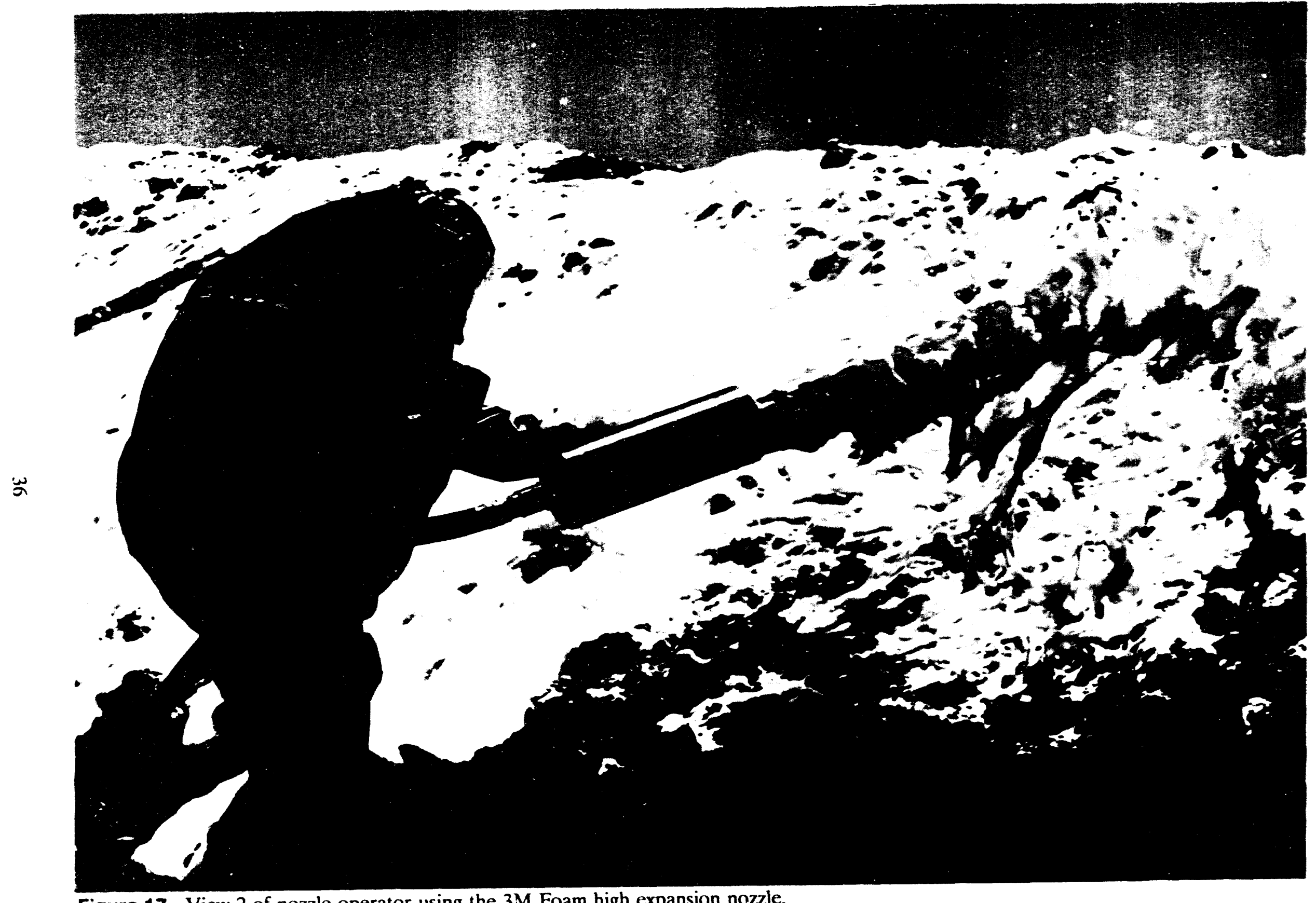

Figure 17. View 2 of nozzle operator using the $3 \mathrm{M}$ Foam high expansion nozzle. 


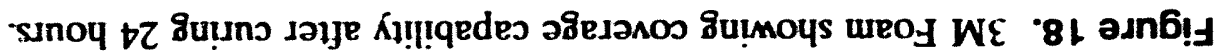

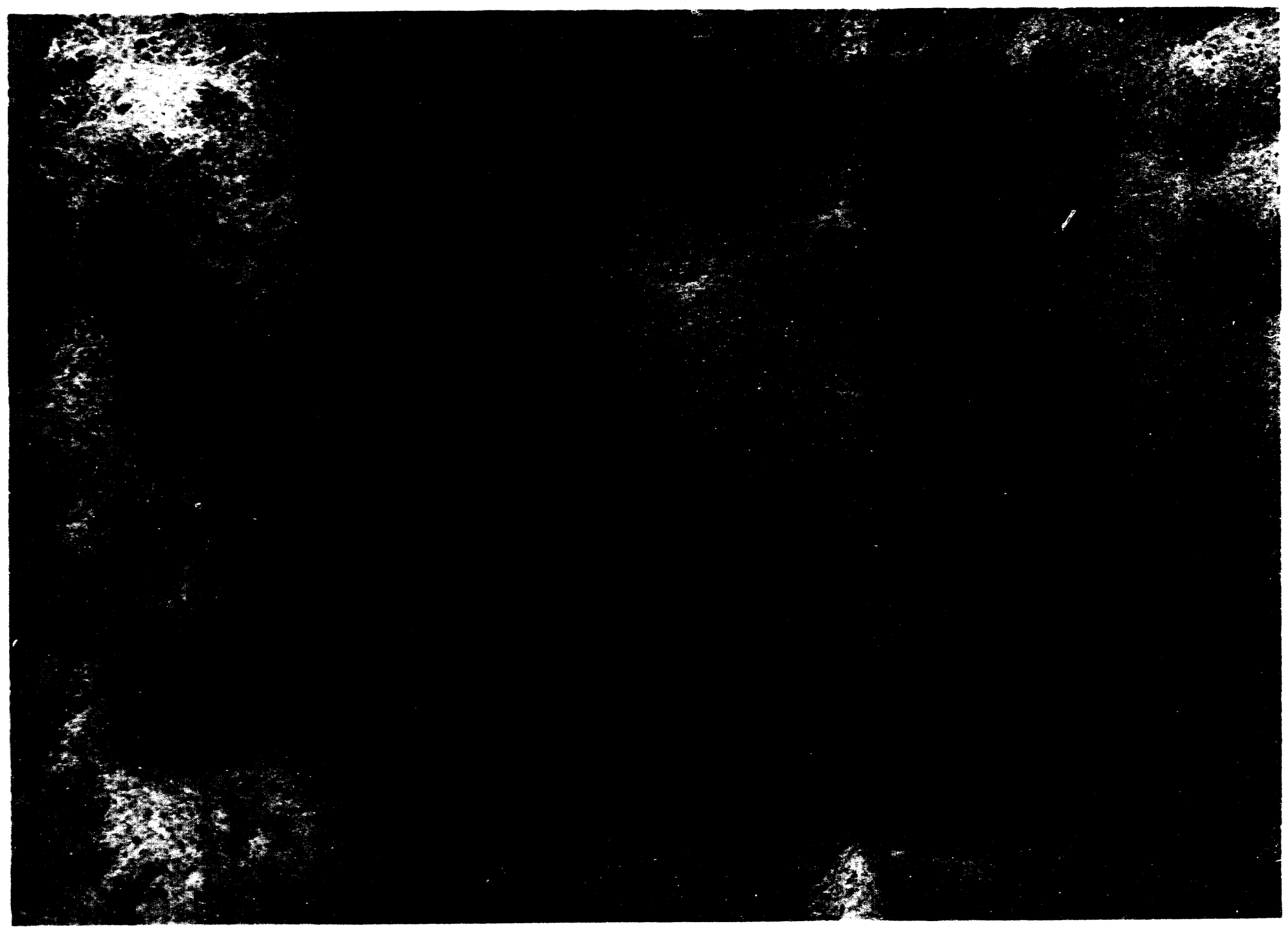




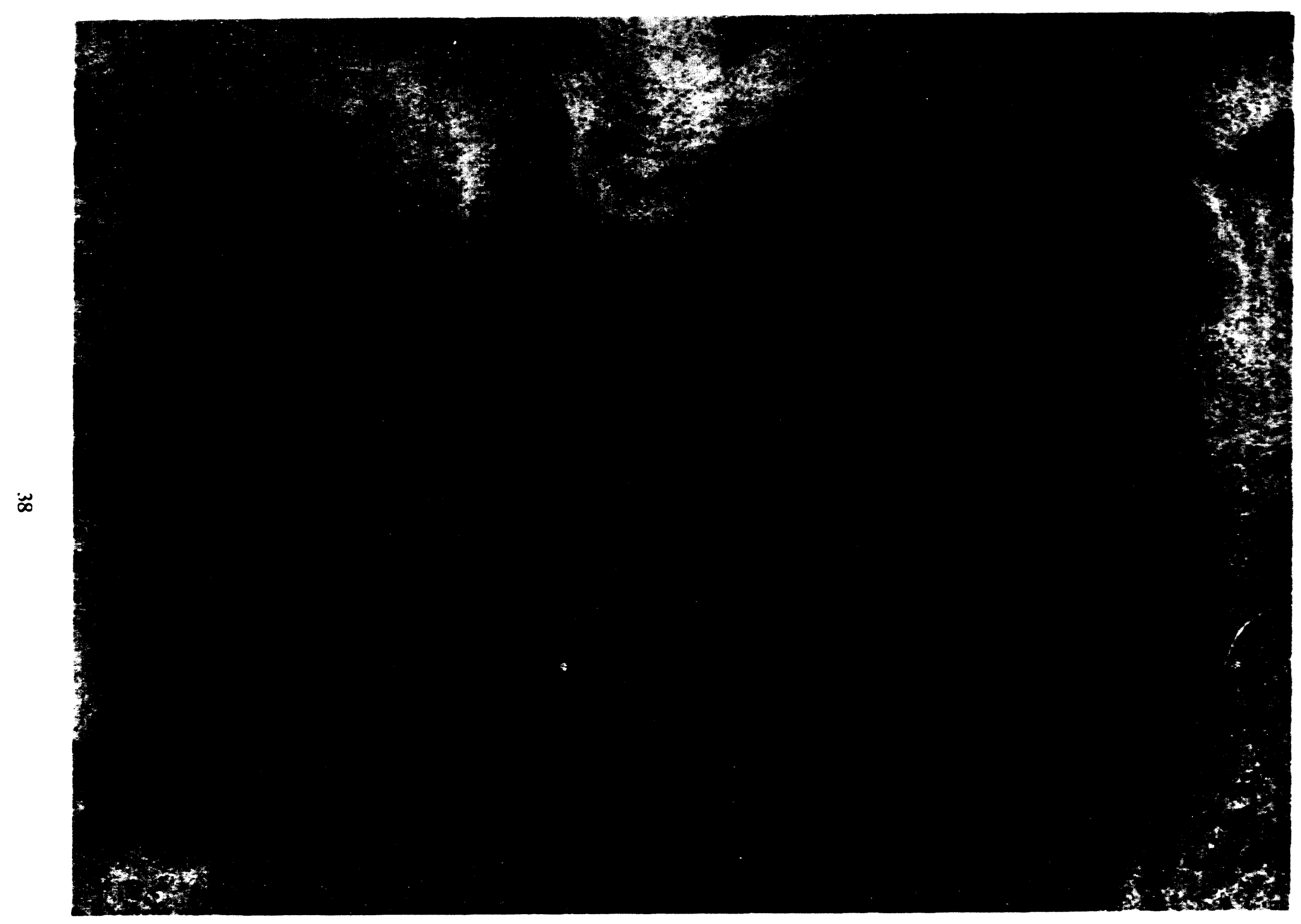

Figure 19. Cured 3M Foam. 


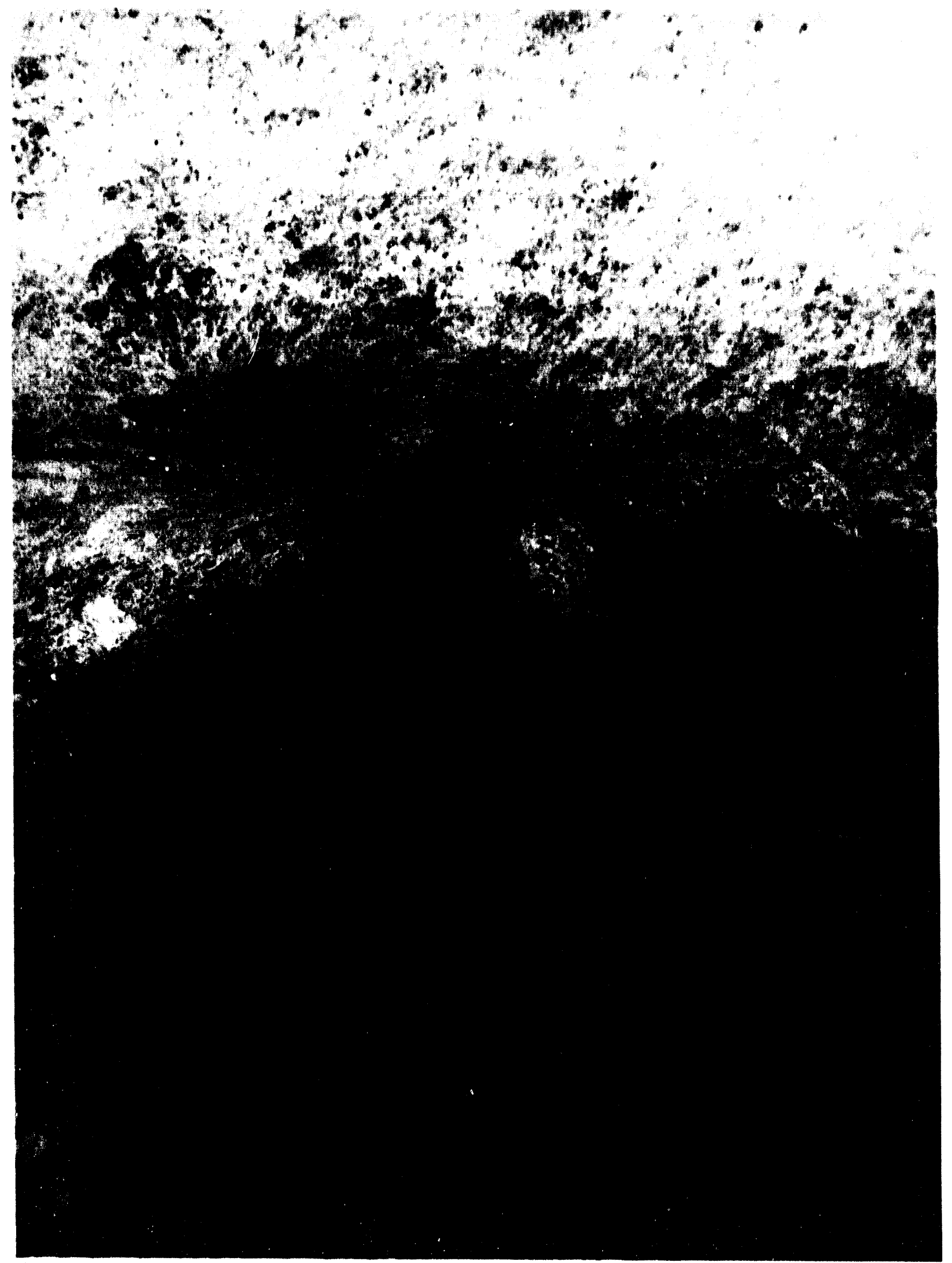

Figure 20. Cured 3M Foam showing its clasticity. 

operations had to be delayed periodically to check on the personnel dressed in the suits. There were no problems with the bubble suits when spraying Cell 4 because of the lessons learned from the east face tests.

\subsubsection{Cell 4 of the CTP}

Contamination control support using the 3M Foam for the RES demonstration showed no results (see Section 6.7) because the waste container debris and dirt were continually dropped onto the samplers near the waste box. In one case, a sampler was knocked over for about 2 minutes until it was righted. As Cell 4 was excavated, beginning with the side without contamination control, more and more waste was uncovered. By the time excavation began on the side of the eell receiving contamination control, the waste forms (30) and 55-gal cardboard barrels) had been torn up, making it difficult for the RES to remove the waste easily. By the time the excavation of Cell 4 was complete, there was waste debris all around the three sampling stands (almost burying them) in front of the waste box. The filter results showed a negative dust control efficiency (see Table 3 in Appendix A) that meant more dust was created during contamination control than without it.

The foam was sprayed four times intermittently during the excavation of Cell 4 , and misting was performed during all digging and dumping operations. In some areas of the cell. the form pooled to a $1 \mathrm{ft}$ depth. Since the foam had only cured for about 5 minutes when digging resumed, some foam adhered to the backhoe bucket of the RES. This could not be easily removed until the foam had rubbed off from further digging or until it had cured at least 24 hours and could be scraped or brushed off the equipment.

\subsection{Stage 3 Results of the Potato Starch System}

The potato starch mixed with water has a milky white translucent color and greasy texture. The mixing ratio of starch 10 water was $300 \mathrm{~mL}$ starch to $4 \mathrm{~L}$ of water. The starch had to be added to the water at approximately $10 \mathrm{~mL} / \mathrm{second}$ while blending simultaneously with a paint mixer. A slower mixing rate was preferable but became impractical when mixing large quantities. Faster mixing rates caused the starch to conglomerate quickly, and it would not break down or blend with continued mixing. The portable sprayer was able to dispense the product with very little elogging. The nozzle aperture is only $1 / 8 \mathrm{in}$. in diameter, and the conglomerated chunks of product had to compress as they were forced through the nozzle. This product would have been used by the CCU, but there was concern about clogging the $\mathrm{Y}$ strainer in a short time. Currently, a better blending technique is not being investigated. When a better blending technique has been achieved, the CCU will be able to dispense this product readily.

Based on the outdoor tests, it took several hours for the starch mixture to cure to a thin crust (1/4 in.) (see Figure 22). The potato starch did not hold up to heavy foot traffic or vehicular traffic but did well if left undisturbed. Outdoors, the crust maintained its integrity for at least 1 week. Indoors (it was tested inside a tent), it took approximately 24 hours to cure. This product was able to stick to vertical soil surfaces if applied slowly. Indoors, the crust maintained its integrity for over 2 weeks. 


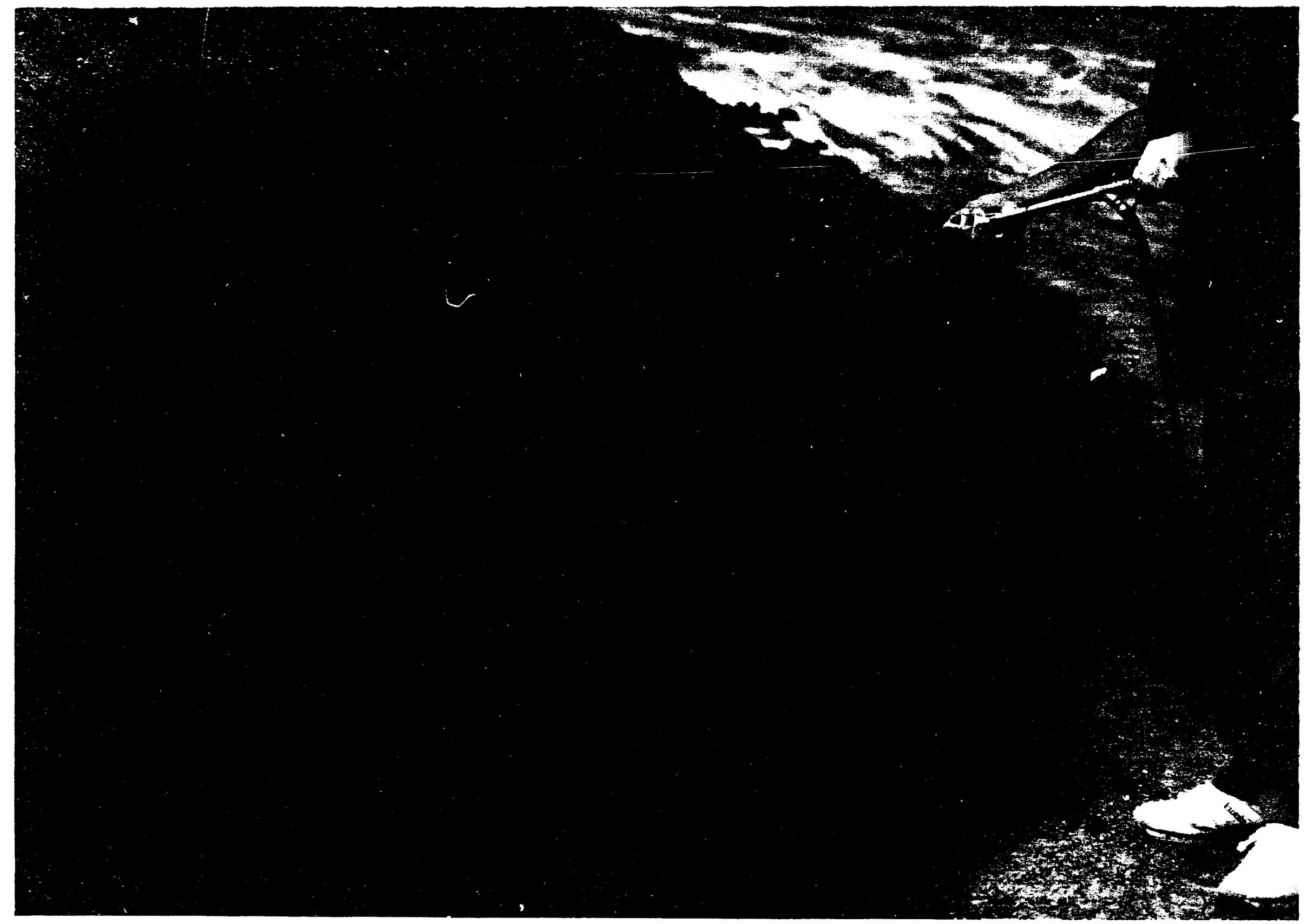




\subsection{Stage 3 Results of the Dust Suppression System}

XDCA (sugar beet polysaccharide) had a strong sweet odor that some workers found offensive. The product had a viscosity similar to water and was relatively easy for the dust suppression pump to suction it from the 55-gal drums to the water tank. The XDCA was mixed in a 2-10-1 ratio of water to product. The mixed solution was dark brown in color.

When sprayed at a rate of $1 \mathrm{gal} / \mathrm{yd}^{2}$ on dry soil, the product cured in 1 to 3 hours and did not withstand any level of disturbance (slightly better than Wen-Don). When sprayed at a rate of 1 $\mathrm{gal} / \mathrm{yd}^{2}$ on prewetted soil, the product cured in 4 to 8 hours, and its suppressing capabilities were improved. Foot traffic on flat surfaces did not disturb its integrity but it was disturbed on rough surfaces. When sprayed at a rate of $2 \mathrm{gal} / \mathrm{yd}^{2}$ on prewetted soil, the product cured in 16 to 30 hours (depending on the weather conditions). At this rate, the performance of XDCA was significantly improved. The treated soil was capable of handling light vehicular traffic on flat surfaces. Heavy foot traffic over rough surfaces continued to break through the suppressant's crust.

Two days after the second application of XDCA ( $1 \mathrm{gal} / \mathrm{yd}^{2}$ on prewetted soil) it rained on and off for several days at the CTP. The XDCA crust was literally rinsed from the application area. Some of the rinsate percolated through the soil, but most of the rinsate drained into a pond (the XDCA was sprayed on a slightly sloped area). The smell of the product was still noticeable in the pond weeks later but not in the application area.

Flambinder (calcium lignosulfonate) had a slight odor similar to the XDCA and was dark brown/black in color. Its viscosity was similar to syrup or molasses. The dust suppression pump could not suction the product from its 55-gal drum. The Flambinder drums were emptied using a drum spigot to drain the suppressant into buckets and poured by hand into the 300 -gal water tank. The calcium lignosulfonate was mixed in a 4-10-1 ratio of water to product.

The mixed solution was sprayed at a rate of $1 \mathrm{gal} / \mathrm{yd}^{2}$ over a prewelted application area. The product cured in 10 to 16 hours. The that surfaces withstood foot traffic, but the rough surfaces did not. When the solution was sprayed at a rate of $2 \mathrm{gal} / \mathrm{yd}^{2}$, the product cured in 16 to 30 hours. The that surfaces withstood light vehicular traffic very well. The rough surfaces withstood light foot traffic but were eventually disturbed as the traflic increased.

Approximately 1 week after the last application, more rain fell on the CTP. The Flambinder percolated 8 to $12 \mathrm{in.}$ into the soil leaving very little trace of the product on the surface (the application area was relatively flat). Several weeks later a 12-in. deep trench was cut across this area for future water drainage. The excavated soil created a berm along the trench. This berm revealed the percolated suppressant. Not only was the odor present again, but the soil was darker in color.

Of the three dust suppressants tested by the CCU, Flambinder was the best overall. XDCA was adequate, and both are far superior to the Wen-Don product. 


\subsection{Stage 3 Quantitative Dust Measurement Results}

Quantitative dust spread data was obtained to evaluate the effectiveness of the CCU to investigate dust spread in a field application. Dust measurements were made using low-volume air samplers with filters for cases of excavation with and without dust control applications, as discussed in Section 5.3.5.

Evaluation of the quantitative data was complicated by the lack of control of test variables; however, a positive control of dust spread was achieved for a case where variables were minimized. Data were obtained for excavation of threc cells (Cell 1, Cell 3, and Cell 4). For Cell 1, variables applied were higher-than-normal soil moisture (approximately $15 \%$ water by mass), the presence of gravel and sand, and a nonuniform waste soil matrix for the side of the cell that used contamination control compared to the side without contamination control. For Cell 1, the average dust concentration (see Appendix A) for all samplers without contamination control was $4.98 \times 10^{-5} \mathrm{~g} / \mathrm{CF}$-Air, and the average for the case with contamination control was $5.12 \times 10^{-5} \mathrm{~g} / \mathrm{CF}$-Air. For this case, potato starch and misting were used as contamination control schemes. These data show no benelit for using contamination control; however, the biasing factors disallow making this comparison.

For Cell 3, there was excellent unilormity in soil/waste matrix; the soil waste removal process was identical for each site and the soil was dricr (approximately 10\% water by mass). For this case, the concentration without contamination control was $18.35 \times 10^{-5} \mathrm{~g} / \mathrm{CF}$-Air, and for potato starch and misting it was $5.38 \times 10^{-5} \mathrm{~g} / \mathrm{CF}$-Air. This results in a control factor of 3.41 and a control efficiency of $70 \%$, which is directly comparable to previous laboratory results. From this data, it was concluded that the contamination control system worked as planned.

For Cell 4, there was a greater lack of control in that the excavated soil was piled in various locations around the pit and soil/waste was dropped on the samplers. For this case, the soil moisture content was considerably drier (approximately 5 to $8 \%$ water by mass). For this application, 3M Foam was used with the misting system. The concentration for the case without contamination control was $10.07 \mathrm{~g} / \mathrm{CF}$-Air, and the case with contamination control was $12.8 \mathrm{~g} / \mathrm{CF}$-Air. 


\section{COST ANALYSIS}

The 3M Foam products are the most expensive of any contamination control products tested so far. The average cost is $\$ 2$ per square foot. The product cost to cover the INEL decommissioned reactor contaminated soil area with $3 \mathrm{M}$ Foam would have been $\$ 34,0(0)$. Comparatively, the product cost for spraying Wen-Don was $\$ 1,925$. To spray Flambinder (calcium lignosulfonate) for this same area would have cost approximately $\$ 5,60)$ and $\$ 14,900$ for spraying XDCA (sugar beet polysaccharide).

The Flambinder product cost $\$ 100$ per 55 -gal drum and was diluted to 4 to 1 . The XDCA product cost $\$ 160$ per 55 -gal drum and was diluted to 2 to 1 . Wen-Don cost $\$ 480$ per 55 -gal drum and was diluted 10 to 1 . Potato starch cost $\$ 25$ per 50-lb bag and was diluted 13 to 1 .

Because water and air are the other products used with the misting system, cost analysis is not applicable. Similarly, the vacuum system does not have an applicable product cost analysis. follows:

Operating costs for the unit, including mobilization and demobilization costs and labor, are as

- Delivery costs are approximately $\$ 2 \mathrm{~K}$ anywhere in the United States.

- Operating technician costs are approximately $\$ 2,400$ per week, based on a 5-day, 40-hour week, excluding per diem. The unit can use onsite technicians or operators but requires an INEL technician for training and oversight.

These costs are based on a deployment of the CCU at the Hanford Site during a retrieval treatability study. 


\section{LESSONS LEARNED}

\subsection{Stage 1}

During testing at a fixed laboratory, it was noticed that the slightest amount of wind altered the misting capabilities significantly. Therefore, misting should be done in a wind controlled environment. There was also some initial confusion when connecting the misting head hoses to the manifold where the water hose was mistakenly connected to the air supply and vice versa. This caused no damage or problem to the system, but the heads did not mist properly (water dribbled from the heads). This situation was resolved by clearly labeling all connections on the manifold and hoses.

The original design of the vacuum system proposed having the debris canister reside in the trailer. After testing and further discussion, it was decided that the debris canister should be positioned outside the trailer on a pallet. There was the potential for two problems to occur that made this change necessary. First, the canister or drum could become too heavy to move with the drum mover for disposal (when full, the drum could weigh $500 \mathrm{lb}$ or more), and second, if the vacuum system is treating radioactively contaminated soil and/or debris, the internal surfaces of the vacuum system will become contaminated from the end of the hose (or attachment) to the HEPA filter located in the vacuum housing. The most significant aspect of the problem concerns removing and replacing the lid to the debris canister. This will have to be done outside of the trailer in a zoned area (probably using a glove box or glove bag containment). Attempts to remove or replace the canister lid inside the trailer could causc contamination sprcad throughout the trailer. It is expected that the hose will be contaminated to a certain degree. At some point, a determination will be made for removing the hose for disposal or decontamination. The vacuum motor and housing are protected by the HEPA filter at the inlet of the vacuum housing.

Using the vacuum system in a radioactively contaminated area or on loosely contaminated items will provide the most useful information and results.

\subsection{Stage 2}

During operations at the INEL decommissioned reactor area, an operator damaged one of the plastic elbows in the plumbing line of the dust suppression system and the line broke. Wen-Don leaked heavily all over the floor of the CCU and required extensive cleanup. It was immediately necessary to replumb the line to continuc operations. The entire line was replaced with metal, which was done with only a few hours of down time. Since replacement, there have not been any problems. Also, as a consequence of this situation, the floor of the CCU had several holes drilled through it for drainage. Rubber stoppers are used to plug these holes during transit.

The suction capability of the dust suppressant system was very difficult to regulate without losing prime to the pump. Losing prime to the pump was one of the reasons the original pump failed and had to be replaced. Two extra ball valves were plumbed in and two bleed valves added. The suction line now works well when the product viscosity is suitable (close to water). 
The pressure gauges initially installed in the misting and dust suppressant systems were found to be inadequate (one burst and one filled with water) and were replaced with oil filled gauges with snubbers. Since replacement, there has been no problem.

Because of the clogging problems associated with the Wen-Don product, a $Y$ strainer was added to the dust suppressant system. This has helped, but not cured, the elogging problems. Particulate from the water truck have entered the system and clogged the misting heads and spray nozzle of the dust suppressant system.

When using the soil fixative system during Stage 2, it was discovered that the flush valve on the blue box was labeled in a confusing manner. When the first attempt at spraying was tried, the flush valve was checked and thought to be closed. However, when the pump was started, water was injected into the FX-9161 pail causing an immediate reaction. The entire 5-gal pail began curing into a foam similar to dense packing material for shipping. Once the water was introduced into the pail, there was no stopping the reaction. The test had to be aborted. The flush valve was rechecked, and it was decided that the label had to be improved.

As more experience was acquired with this system, we realized that using the flush valve on the blue box was not necessary. Instead of using the flush valve and causing the FX-9161 product to be momentarily evacuated onto the ground at the blue box (which eventually made a muddy mess that was hard to clean up), it was determined that the product hoses from the blue box could be switched to two 5-gal buckets of water. This permitted proper flushing of the system and made no mess on the ground near the blue box and product pails.

When turning on the fixative pump, it was learned that the product hoses in the blue box should remain out of the 5-gal product pails until water is flowing out of the expansion nozzle; then the hoses can be inserted into the product pails. For a second or two, water can escape from the product hoses and go into the product pails causing a reaction with the FX-9161 as described above.

After donning SCBA and bubble suits, personnel should walk around for a few minutes and get accustomed to the sense of confinement. Two of the four people that wore the suits had a claustrophobic reaction. This anxiety can also accelerate heat stress if the conditions exist. Communicating with one another was a major problem that was not recognized as overly significant until the anxiety reactions occurred. Prejob bricfing should include a varicty of hand signals to be used while in the suits. Although hand signals for the spray operation were used, there were no signals for emergency situations.

\subsection{Stage 3}

Using the $3 \mathrm{M}$ Foam product as a soil fixative for the Cell 4 digging operation proved to be inappropriate. Using $3 \mathrm{M}$ Foam for this operation is similar to laying a piece of paper or plastic over the pit for contamination control and digging through it. A more appropriate product would be the calcium lignosulfonate or the potato starch product. The $3 \mathrm{M}$ Foam product is more appropriate for longer-term (day long or longer) fixation of a digface that will be left undisturbed. 


\section{CONCLUSIONS}

Based on the examination of the results of these demonstrations, the following observations are offered.

The CCU performed as expected during Stage 3. The CCU did not have any down time and all systems worked properly. Personnel operating the CCU became experienced and proficient by the end of the demonstrations.

Using the Dryfog Ultrasonic Misting System to control acrosolized soil provided visual dust control. Misting in wind controlled conditions was very effective. Wind altered the misting capabilities significantly; therefore, misting should be done in a wind controlled environment.

The 3M Foam is an excellent product but has cost constraints. The key to optimum performance of $3 \mathrm{M}$ Foam is using the product for the proper situation and under the right conditions. Applying the $3 \mathrm{M}$ Foam product as a soil fixative for the Cell 4 digging operation proved to be inappropriate for a real world application. This was similar to laying a piece of paper or plastic over the pit for contamination control and digging through it. Using this product outdoors for an extended amount of time is not desirable because of its breakdown from ultraviolet rays after 1 or 2 wecks. The best situation for this product is covering dry, contaminated soil or covering items with loose contamination that are expected to be left undisturbed inside of a containment structure (e.g., Pit 9 reclamation). Previous tests have shown $3 \mathrm{M}$ Foam to last 3 years or longer indoors when left undisturbed.

The potato starch mixture formed a crust that was not readily solubilized. The crust maintained its integrity for at least 1 week before ultraviolet rays began to degrade its quality. The starch adhered to vertical soil slopes extremely well when applied slowly. This product was better suited than 3M Foam to fix the soil during RES operations of Cells 1 and 3 because the solution soaked into the soil to form its crust and did not behave like a blanket.

Wen-Don did not withstand any traffic or disturbances and its ability to suppress dust or contamination was poor. The applied product did not resolubilize and behaved as a soil fixative or an encapsulant with limited capability.

Flambinder was an adequate dust suppressant for short-term control. It had the best ability to withstand heavy foot traffic and light vehicular traffic. When given 1 hour to cure completely, the soil surface became very hard and resilient to all traffic. Uncured or partially cured product resolubilized easily, which degraded the dust suppressing quality.

XDCA proved to be an adequate dust suppressant if applied on prewetted soil. It did not endure traffic as well as the Flambinder, but it was equal in quality when compared in undisturbed applications.

Of all of the products tested by the CCU, Flambinder was the best overall. XDCA is also adequate and both are lar superior $10 \mathrm{Wen}$-Don for the applications tested. Flambinder was best suited lor contamination control in trallic areas, in the excavation area, and on the dumping area. The XDCA was best suited for contamination control on smooth, light traffic areas, and also in the 
excavation area, and on the dumping area. The potato starch was best for short-term steep diglace fixation of dust and loose contamination.

Quantitative evaluation of the air sampler data, for excavation cases with and without contamination control, showed that if test variables were controlled, the CCU achieved laboratory levels of dust control in the field application. For the case in Cell 3 where the variables were minimized, a control factor of $\mathbf{3 . 4}$ and an air control efficiency of $70 \%$ was achieved. 


\section{RECOMMENDATIONS}

The CCU is ready for field deployment. The CCU was transported in the fall of 1993 to the Westinghouse Hanford Site at the 100) F Arca. Surfactants, dust suppression agents, crusting agents (soil fixatives), and the misting system were applied to excavation operations of contaminated soil from the 116-F.4 waste sitc (a 100) F Area pluto crib) to control TRU and low-level soil contamination and to support the testing of different types of dust control products.

The misting system is now equipped with six misting heads (instead of four), misting hoses that can be lengthened or shortened with quick disconnect fittings, and adjustable stands to spray from a position of 1 to $18 \mathrm{ft}$ high above the dust source. The water-to-air ratio of the misting heads needs to be further evaluated.

The CCU is ready as an emergency response unit. There are products immediately available to provide contamination control using stoil fixation (3M Foam) and dust suppression (Flambinder), if the need arises. The misting and vacuum systems are always available. The CCU can be moved throughout the DOE complex for use (e.g.. Fernald, Savannah River Site, and Hanford Site).

The systems in the CCU have proven to be ready for a full-scale test or application.

The vacuum system needs further evaluation using spiked sieved soil with rare earth tracer. The vacuum system could operate until the debris container is full using the rare earth tracers in soil. Change out of the containers would be performed with air samplers around the debris container. Smears would be taken from the inner surfaces of the vacuum system and analyzed, along with the air sampler filters, for tracer. This test would demonstrate the contamination control of the vacuum system and identify possible contamination problems when using this system. 


\section{REFERENCES}

1. M. R. Winberg and V. E. Wixom. Fugitive Dust Control Experimemts Using Soil Furative's om Vehicle Traffic Surfaces, EGG.WTD-1(13.54, August $1(9) 2$.

2. M. R. Winberg. R. J. Pawelko, N. C. Jacobs, and D. N. Thompson. Engineering Scale Dust Control Experiments, EGG.WTD-(19.387, 1991.

3. S. W. Duce, M. R. Winberg, and A. L. Frecman, Basic Radiological Studies Contamination Control Experiments, EGG-WM-8272, Scptember 1989.

4. M. R. Winberg and D. N. Thompson. Test Plan for the Field Evaluation and Demomstration of the Contamination Control Unit, EGG.WTD-10717, March 1993.

5. A. L. Freeman, D. N. Thompson, and V. E. Wixom. Contamination Control Unit Operations Manual, EGG.WTD.10886, August 1993. 


\section{Appendix A}

Quantitative Air Sampling Data 


\section{Appendix A}

\section{Quantitative Air Sampling Data}

Appendix $A$ includes summarized data on dust loadings collected on air samplers strategically located around the site of excavation. Cells 1, 3, and 4 of the Cold Test Pit (CTP) used this sampling system. This appendix contains tabularized data and a sketch of the sampler locations for each of these cells.

The control efficiency is the dust loading per volume of sampled air (concentration) with no contamination control (baseline) minus concentrations with contamination control divided by the bascline concentration times $100 \%$. A control factor is also calculated, which is a simple ratio of the baseline concentration divided by the contamination control concentration. For example, if the control efficiency is negative, there is an indication of poor control. If the control factor is greater than one, there is an indication of a positive contamination control result. 
REMCTE EXCAVATION SYSTEM

SOIL AND SIMULATED TRU GURIEO WASTE REMOVAL

JUNE/JULY 1993

\begin{tabular}{|c|c|c|c|c|}
\hline TEST 10: & \multicolumn{4}{|c|}{93063001 out } \\
\hline \multicolumn{5}{|c|}{ TOTAL SAMPLING } \\
\hline \multirow[t]{2}{*}{ TIME (MIN) } & 99 & & & \\
\hline & \multicolumn{4}{|c|}{ NO CONTAMINATION CONTROL } \\
\hline SAMPLE & SAMPLER & AVG FLOW & NET DUST & CONCENTRATION \\
\hline \pm 0 & LOCATION & $\mathrm{CF} / \mathrm{m}+\mathrm{n}$ & LOADING (G) & $G$ DUST/CF-AIR \\
\hline$x=n=m=0$ & 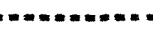 & $-=-\infty+\infty=0$ & 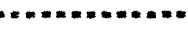 & 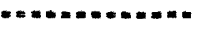 \\
\hline RESLV127 & LV 1 & 1.752 & 0.0079 & $4.554 E-05$ \\
\hline RESLV128 & LV 2 & 2.535 & 0.0072 & $4.737 E-05$ \\
\hline RESLV1 29 & LV 3 & 1.645 & c. 0092 & $5.648 E-05$ \\
\hline RESLV130 & LV 4 & 1.714 & 0.0081 & $4.773 E-05$ \\
\hline RESLV13: & LV 5 & 2.422 & c.0098 & $4.087 E-05$ \\
\hline RESLV 132 & LV : & 1.734 & $c .0058$ & $3.379 E-05$ \\
\hline RESLV 133 & LV 7 & 2.044 & 0.0135 & $6.671 E \cdot 05$ \\
\hline RESLV134 & LV 8 & 2.535 & $c .0069$ & $4.540 E-05$ \\
\hline RESLV135 & LV 9 & 2.496 & 0.0107 & $4.331 E-C 5$ \\
\hline RESLV1 36 & LV 10 & 2.442 & c. 0123 & $5.087 E-05$ \\
\hline RESHV0 37 & HV 1 & 19.35 & 0.1256 & $6.557 E-05$ \\
\hline RESHV038 & HV 2 & $19.7 i$ & $0.13 \div 3$ & $7.121 E-0.5$ \\
\hline
\end{tabular}

CELL \#1B

TEST ID 93063002 . out

TOTAL SAMPLING

TIME (MIN) : $\quad 105$

CONTAMINATION CONTROL

\begin{tabular}{|c|c|c|c|c|c|c|}
\hline $\begin{array}{l}\text { SAMPLE } \\
\text { ID }\end{array}$ & $\begin{array}{l}\text { SAMPLER } \\
\text { LOCATION }\end{array}$ & $\begin{array}{l}\text { AVG FLOW } \\
\text { CF/min }\end{array}$ & $\begin{array}{c}\text { NEI DUST } \\
\text { LOADING (G) }\end{array}$ & $\begin{array}{l}\text { CONCENTRATION } \\
\text { G DUST/CF-AIR }\end{array}$ & $\begin{array}{l}\text { CONTROL } \\
\text { EFFICIENCY }\end{array}$ & $\begin{array}{l}\text { CONTROL } \\
\text { FACEOR }\end{array}$ \\
\hline RESLV14I & LV 1 & 1.750 & 0.0083 & 4. $517 E-05$ & 0.82 & 2.01 \\
\hline RESLV14 2 & LV 2 & 1.496 & 0.0080 & 5. $093 E-05$ & -7.50 & 0.93 \\
\hline RESLV143 & LV 3 & 1.588 & c. 0096 & 5. $758 \mathrm{E}-05$ & -1.95 & 0.98 \\
\hline RESLV144 & LV 4 & 1.695 & 0.0139 & $7.909 \varepsilon-05$ & -63.62 & 0.61 \\
\hline RESLV145 & LV 5 & 2.429 & 0.0177 & $6.970 E-05$ & .70 .54 & 0.59 \\
\hline RESLVIAE & LV 6 & 1.707 & 0.0054 & $3.013 F-05$ & 10.84 & 1.12 \\
\hline RESLVI 47 & LV 7 & 2.009 & c. 0090 & $4.267 \mathrm{E}-05$ & 36.03 & 1. 56 \\
\hline RESLV148 & LV 8 & 1.513 & 0.0086 & $5.414 E-05$ & .19 .25 & 0.84 \\
\hline RESLV149 & LV 9 & 2.468 & 0.0206 & 4.090E-05 & 5.56 & 1.06 \\
\hline RESLV150 & LV 10 & 2.306 & 0.0115 & A $750 E-05$ & 6.64 & 107 \\
\hline
\end{tabular}

NO HV DATA RESHV043-RESHV047 IS MISSING FROM ECU REPORT 


\section{CELL 1 EXCAVATION SETUP}

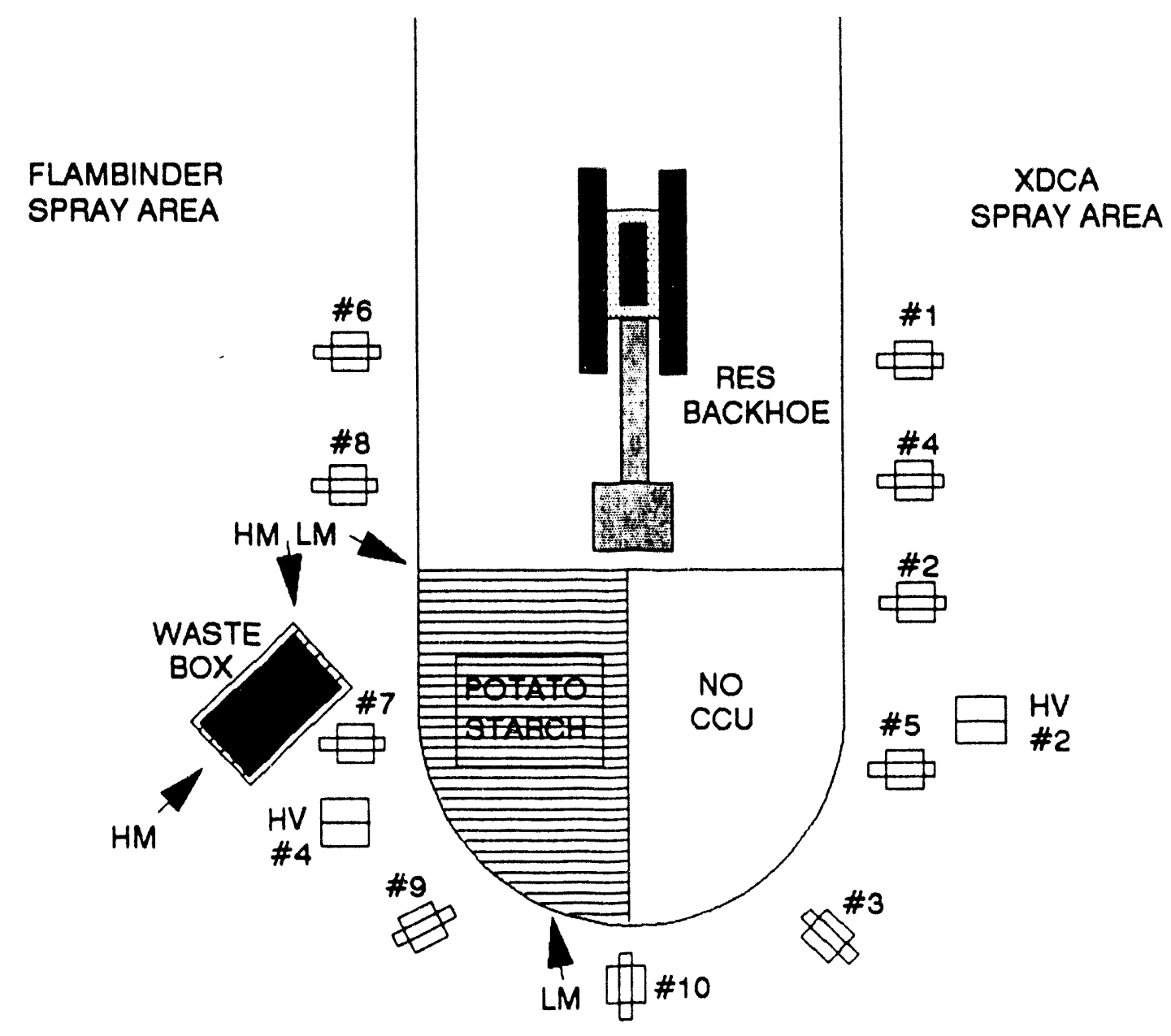

$$
\begin{aligned}
& \text { HM }=\text { HIGH STAND MISTER } \\
& \text { LM = LOW STAND MISTER } \\
& =\text { = LOW-VOLUME SAMPLER } \\
& =\text { HI-VOLUME SAMPLER }
\end{aligned}
$$


REMOTE EXCAVATION SYSTEM

SOIL AND SIMULATED TRU BURIED WASTE REMOVAL JUNE/JULY 1993

CELL \#3A

TEST ID: $\quad 93070101$. OUT

TOTAL SAMPLING

TIME (MIN) :

22

NO CONTAMINATION CONTROL

SAMPLE SAMPLER AVG FLOW NET DUST CONCENTTRATION

ID LOCATION CF/min LOADING (G) G DUST/CF-AIR

\begin{tabular}{|c|c|c|c|c|c|}
\hline RESLV155 & $\mathrm{LV}$ & 1 & 1.766 & 0.0035 & $9.009 E-05$ \\
\hline RESLV156 & $\mathrm{LV}$ & 2 & 1.540 & 0.0090 & $2.656 \mathrm{E}-04$ \\
\hline RESLV157 & LV & 3 & 1.667 & 0.0057 & 1. $554 \mathrm{E}-04$ \\
\hline RESL/158 & $\mathrm{LV}$ & 4 & 1.716 & 0.0000 & $0.000 \mathrm{E}+00$ \\
\hline RESLV159 & LV & 5 & 2.390 & 0.0102 & 1. $940 \mathrm{E}-04$ \\
\hline RESLV160 & LV & $\overline{0}$ & 1.723 & 0.0083 & $2.190 E-04$ \\
\hline RESLV161 & LV & 7 & 2.013 & 0.0068 & $1.535 E-04$ \\
\hline RESLV162 & LV & 8 & 1.515 & 0.0148 & $4.440 E-04$ \\
\hline RESLV163 & $\mathrm{LV}$ & 9 & 2.509 & 0.0035 & $6.341 E-05$ \\
\hline RESLV164 & LV & 10 & 2.312 & 0.0034 & $6.684 \mathrm{E}-05$ \\
\hline RESTN $) 47$ & $\mathrm{HiV}$ & i & 29.35 & & \\
\hline RESHV04 8 & HV & 2 & 19.76 & 0.0486 & :. $118 \mathrm{E}-04$ \\
\hline RESHV049 & $\mathrm{HV}$ & 4 & 20.34 & 0.0624 & $1.394 E-04$ \\
\hline
\end{tabular}

CELL \#3B

TEST ID: $\quad 93070201$. CUT

TOTAL SAMPLING

TIME (MIN) :

51

CONTAMINATION CONTROL

\begin{tabular}{|c|c|c|c|c|c|c|}
\hline SAMPLE & SAMPLER & AVG FLOW & NET DUST & CONCENTRATICN & CONTROL & CONTROL \\
\hline ID & LOCATION & $\mathrm{CF} / \mathrm{min}$ & LOADING (G) & G DUST/CF-AIR & EFFICIENCY (q) & FACTOR \\
\hline 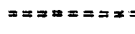 & 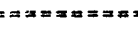 & 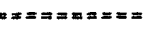 & 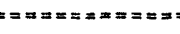 & 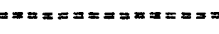 & $=z=\equiv=x=$ & 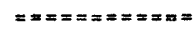 \\
\hline RESLV169 & LV 1 & 1.738 & 0.0043 & 4. $851 E-05$ & 46.15 & 1.86 \\
\hline RESLVI70 & LV 2 & 1.505 & 0.0049 & $6.383 E-05$ & 75.97 & 4.16 \\
\hline RESLV171 & LV 3 & 1639 & 0.0057 & $6.819 E-05$ & 56.13 & 2.28 \\
\hline RESLV172 & LV 4 & 1.693 & 0.0052 & $6.024 \mathrm{E}-05$ & & \\
\hline RESLVI73 & LV 5 & 2.349 & 0.0083 & $6.929 E-05$ & 64.27 & 2.80 \\
\hline RESLV174 & LV 6 & 1.700 & 0.0038 & 4. $383 E-05$ & 79.98 & 5.00 \\
\hline RESLV175 & LV 7 & 2.005 & 0.0045 & $4.401 E-05$ & 71.33 & 3.49 \\
\hline RESLV176 & LV 8 & 1.506 & 0.0057 & $7.421 E-05$ & 83.29 & 5.98 \\
\hline RESLV177 & LV 9 & 2.480 & 0.0033 & $2.6105-05$ & 58.85 & 2.43 \\
\hline RESLV178 & LV 10 & 2.255 & 0.0046 & 4. 000 E- 05 & 40.16 & 1.67 \\
\hline RESHV050 & HV 1 & 19.35 & 0.0508 & $5.148 \mathrm{E}-05$ & & \\
\hline RESHVC 51 & HV 2 & 19.76 & 0.0525 & $5.210 E-05$ & 53.40 & 2.15 \\
\hline RESHV0 52 & HV 4 & 20.34 & 0.0476 & $4.589 E-05$ & 67.09 & 3.04 \\
\hline
\end{tabular}




\section{CELLS 3A AND 3B EXCAVATION SETUP}

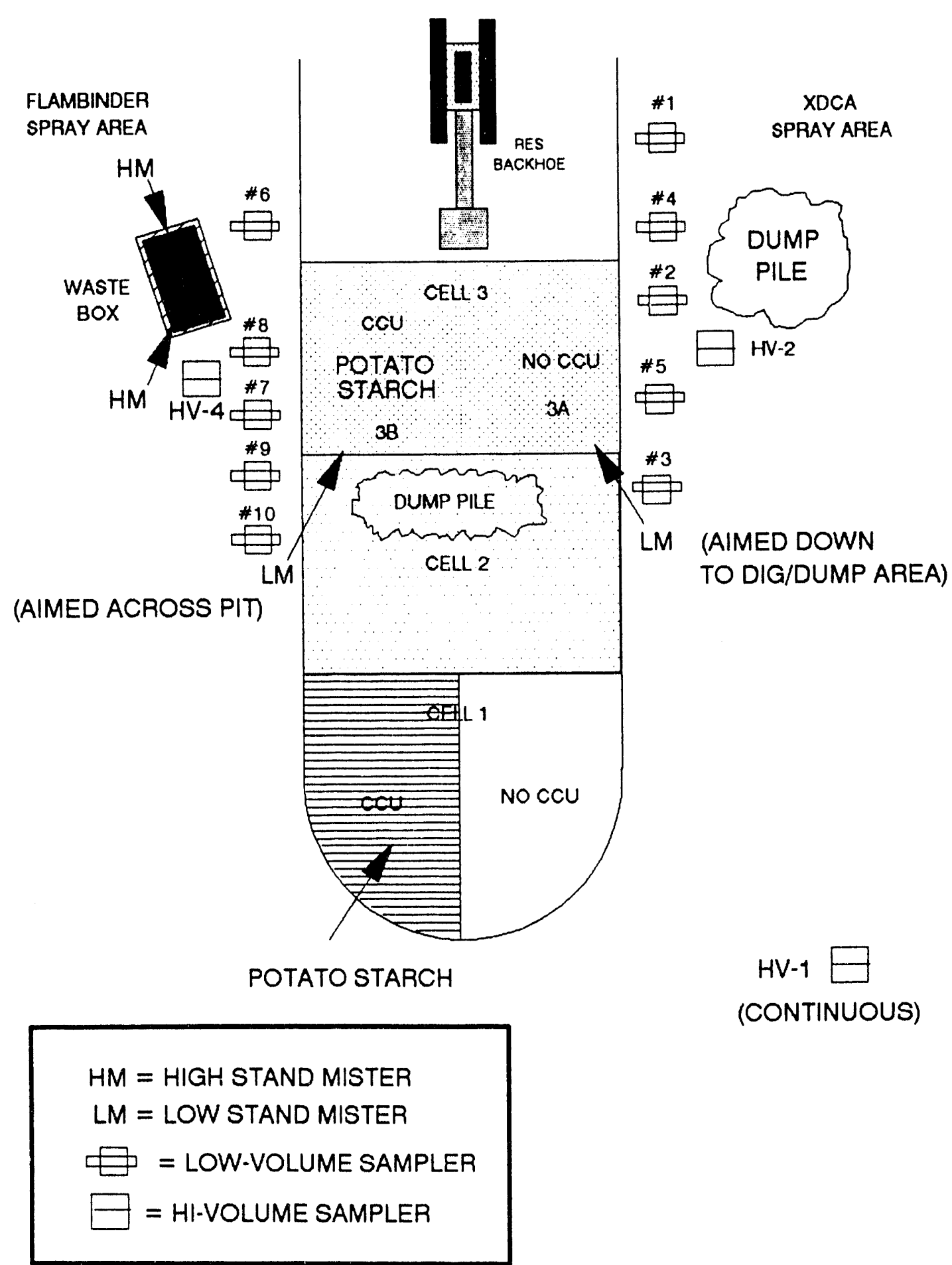


REMOTE EXCAVATION SYSTEM

SOIL AND SIMLLATED TRU BURIED WASTE REMOVAL

JUNE/JULY 1993

\begin{tabular}{|c|c|c|c|c|c|}
\hline TEST ID: & 93070 & 0701. & . OUT & & \\
\hline \multicolumn{6}{|c|}{ TOTAL SAMPLING } \\
\hline \multirow[t]{2}{*}{ TIME (MIN) } & \multicolumn{5}{|c|}{70} \\
\hline & \multicolumn{5}{|c|}{ NO CONTAMINATION CONTROL } \\
\hline SAMPLE & SAMPL & & AVG FLOW & NET DUST & CONCENTRATION \\
\hline ID & LOCAT & TION & $\mathrm{CF} / \mathrm{min}$ & LOADING (G) & G DUST/CF-AIR \\
\hline$=x z=x=x=0$ & 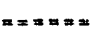 & $=x==$ & $x=x=x=x=x$, & 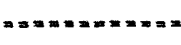 & 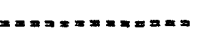 \\
\hline RESLV183 & LV & 1 & 1.740 & 0.0052 & $4.270 E-05$ \\
\hline RESLV184 & LV & 2 & 1.524 & 0.0043 & $4.030 E-05$ \\
\hline RESLV195 & LV & 3 & 1.648 & 0.0048 & $4.162 \mathrm{E}-05$ \\
\hline RESLV186 & LV & 4 & 1.692 & 0.0069 & $5.826 E-05$ \\
\hline RESLV187 & LV & 5 & 2.351 & 0.0109 & $6.625 \mathrm{E}-05$ \\
\hline RESLV188 & LV & 6 & 1.093 & 0.0137 & $1.156 \mathrm{E}-04$ \\
\hline RESLV189 & LV & 7 & 1.982 & 0.0201 & $1.449 E-04$ \\
\hline RESLV190 & LV & 8 & 1.509 & 0.0261 & $2.471 E-04$ \\
\hline RESLV191 & LV & 9 & 2.505 & 0.0166 & $9.466 \varepsilon-05$ \\
\hline RESLV1 92 & $i v$ & 10 & 2.317 & 0.0252 & $1.554 E-04$ \\
\hline RESHV057 & IV & 1 & 19.35 & 0.0744 & $5.493 \mathrm{E}-05$ \\
\hline RESHV058 & 48 & 2 & 19.76 & 0.0666 & $4.815 E-05$ \\
\hline RESHV059 & HV & 4 & 20.34 & 0.0785 & $5.513 E-05$ \\
\hline
\end{tabular}

CELL \#4B

TEST ID: $\quad 93070801.00 T$

TOTAL SAMPLING

TIME (MIN) :

82

CONTAMINATION CONTROL

\begin{tabular}{|c|c|c|c|c|c|c|}
\hline \multirow{2}{*}{$\begin{array}{c}\text { SAMPLE } \\
\text { ID }\end{array}$} & SAMPLER & \multirow{2}{*}{$\begin{array}{l}\text { AVG FLOW } \\
\mathrm{CF} / \mathrm{min}\end{array}$} & NET DUST & \multirow{2}{*}{$\begin{array}{l}\text { CONCENTRATION } \\
\text { G DUST/CF - AIR }\end{array}$} & \multirow{2}{*}{$\begin{array}{l}\text { CONTROL } \\
\text { EFFICIENCY (z) }\end{array}$} & \multirow{2}{*}{$\begin{array}{l}\text { CONTROL } \\
\text { FACTOR }\end{array}$} \\
\hline & LOCATION & & LOADING $(G)$ & & & \\
\hline$x=x=m=x x$ & $==x=m$ & $z=x=m=0$ & 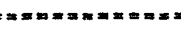 & 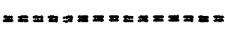 & $x=x=x=x=$ & $y=x=x=x$ \\
\hline RESLV197 & LV I & 1.694 & 0.0177 & $1.274 E-04$ & -198.41 & 0.34 \\
\hline RESLV198 & LV 2 & 1.476 & 0.0104 & $8.590 E-05$ & -113.17 & 0.47 \\
\hline RESLVI99 & LV 3 & 1.608 & 0.0089 & $6.749 E-05$ & -62.16 & 0.62 \\
\hline RESLV200 & LV 4 & 1.653 & 0.0108 & $7.967 E-05$ & -36.76 & 0.73 \\
\hline RESLV201 & LV 5 & 2.307 & 0.0099 & $5.234 E-05$ & 20.99 & 1.27 \\
\hline RESLV202 & LV 6 & 1.668 & 0.0161 & $1.177 E-04$ & -1.79 & 0.98 \\
\hline RESLV203 & LV 7 & 1.941 & 0.0318 & $1.998 \mathrm{E}-04$ & .37 .94 & 0.72 \\
\hline RESLV204 & LV 8 & 1.486 & 0.0306 & $2.511 E-04$ & -1.62 & 0.98 \\
\hline RESLV205 & LV 9 & 2.444 & 0.0347 & $1.732 E-04$ & -82.94 & 0.55 \\
\hline RESLV206 & LV 10 & 2.188 & 0.0242 & $1.349 \mathrm{E}-04$ & 13.18 & 1.15 \\
\hline RESHV06 0 & HV 1 & 19.35 & 0.1162 & $8.5715-05$ & -56.05 & 0.64 \\
\hline RESHY061 & HV 2 & 19.76 & 0.1012 & $7.316 E-05$ & -51.95 & 0.66 \\
\hline RESHV062 & HV 4 & 20.34 & 0.1176 & $8.260 E-05$ & -49.81 & 0.67 \\
\hline
\end{tabular}




\section{CELL 4 EXCAVATION SETUP}

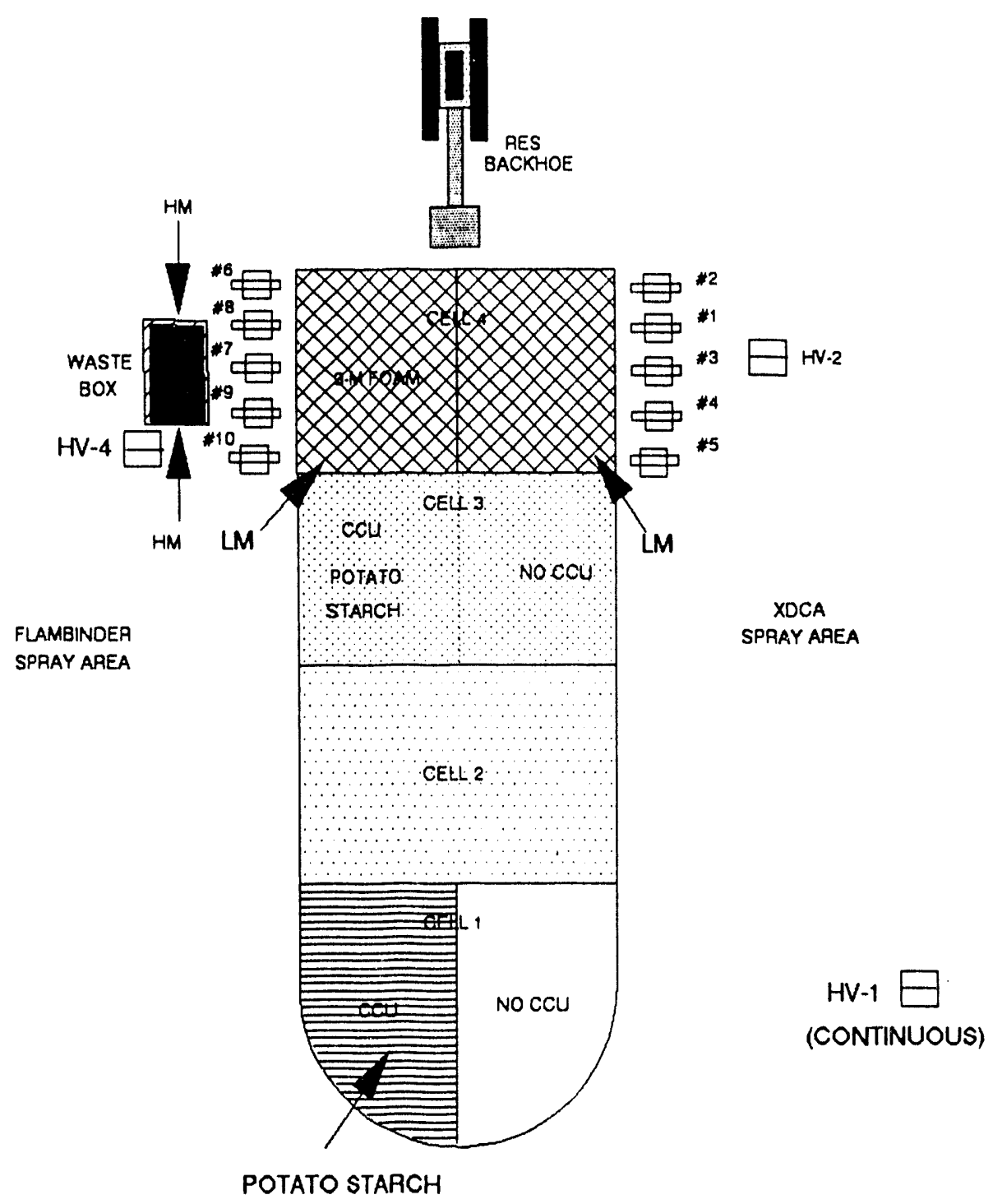

$H M=H I G H ~ S T A N D$ MISTER

$L M=$ LOW STAND MISTER

= LOW-VOLUME SAMPLER

$\theta=$ HI-VOLUME SAMPLER 

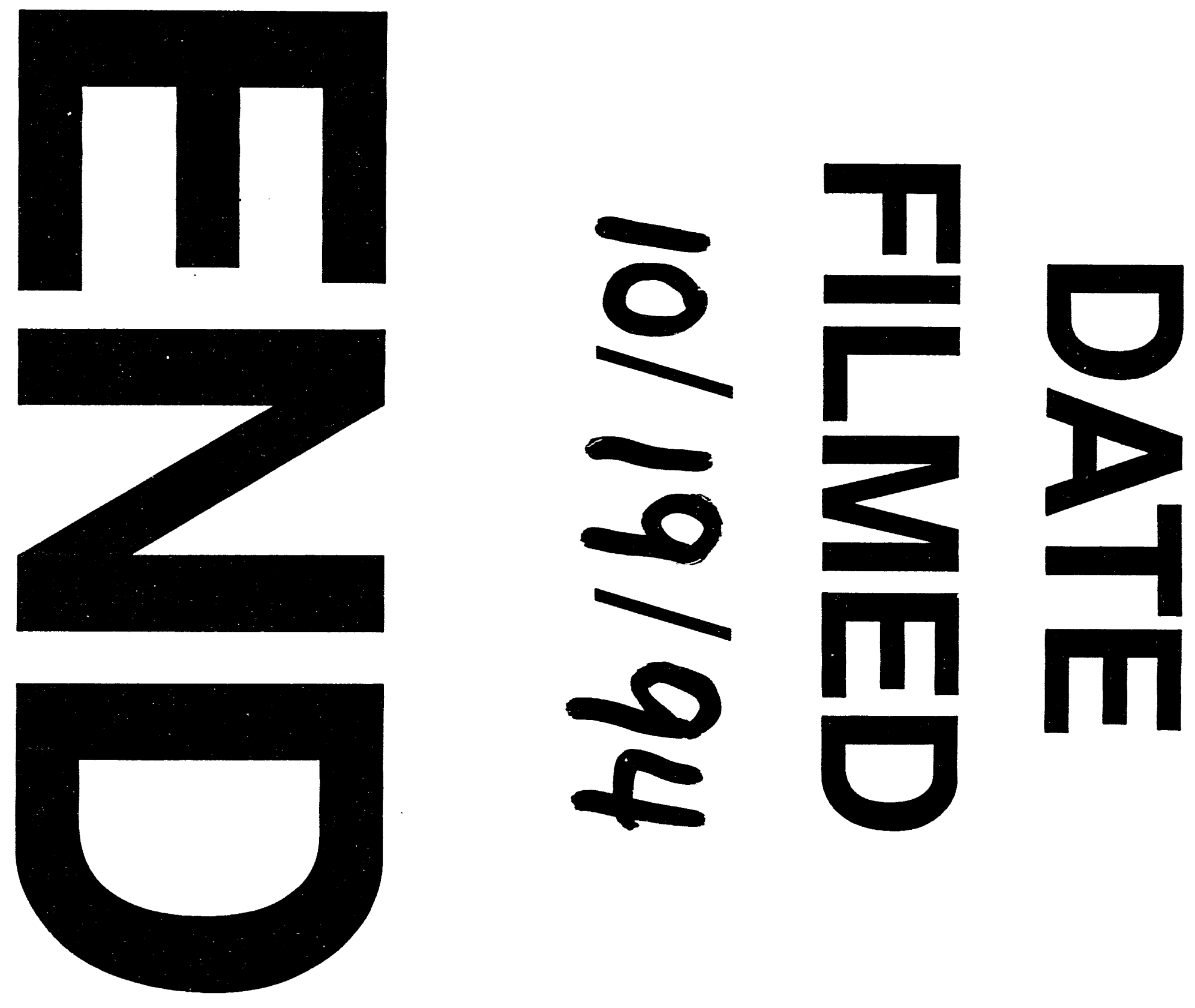
